\title{
Thermal and Metallurgical Effects Associated with Gas Carburized and Induction Hardened Components
}

\author{
K. Palaniradja*, N. Alagumurthi and V. Soundararajan \\ Department of Mechanical Engineering, Pondicherry Engineering College, Pondicherry - 605 014, India
}

\begin{abstract}
Dimensional distortion occurs due to the thermal and transformation stresses formed during the heat treatment processes. Taguchi and Factorial design of experiment concepts were applied to optimize the operating variables involved in the gas carburising and induction hardening processes so as to minimize the geometrical distortions. Experimental data obtained for the materials EN353, EN351, AISI 4140, and AISI 9255 were analyzed by Response graph method and Signal to Noise method. Even though, EN 351 and EN 353 are having the same carbon percentage, EN 353 gives minimal dimensional and volume changes because of the presence of three alloying elements namely cobalt, molybdenum and nickel. Analysis by variance (ANOVA) results indicated that the furnace temperature and quenching time in the gas carburising process were the variables which had more influence on distortion. The percentage deviations between the experimental and predicted results for the runout and helix variations were in the range of 7 to $10 \%$.
\end{abstract}

Keywords: Thermal analysis, Metallurgical effects, surface hardness, helix variation, ANOVA.

\section{INTRODUCTION}

The major problem faced by heat treatment industries is the dimensional and geometrical changes that occur in the heat treated component. One of the main causes for dimensional changes is the stresses, which occur as a consequence of the contraction of the material during cooling, i.e. formation of thermal stresses (thermal effect). The other main cause is the transformation stresses which occur as a result of the marteniste formation (metallurgical effect).

When a body cools, the outer layer cools quicker and contracts first. The inner, softer parts try, during this process, to assume a spherical shape, this being the shape to which they offer the least resistance during deformation. Hence, the main rule is that all bodies with shape deviating from the spherical one attempt to assume this shape during cooling. Bullenes, D.K., (1949) illustrated that more the severity of the quench process greater will be the changes. Greater the rate of temperature drop during cooling greater will be the deformation [1].

On rapid heating and cooling of steel in any heat treatment process, it passes through a series of structural transformations. During heating of steels, a continuous increase in length occurs upto Ac1, where the steel starts shrinking as it transforms into austenite. After the austenite formation is completed, the length increases again. However, the coefficient of longitudinal expansion is not the same for austenite as that for ferrite.

On cooling, thermal contraction takes place and during martensite formation the length of the steel increases. After cooling to room temperature, most martensitic steels contain

*Address correspondence to this author at the Department of Mechanical Engineering, Pondicherry Engineering College, Pondicherry-605014, India; Tel: 91413 2655281-287, Ext. 252,259; Fax: 91413 2655101;

E-mail: palaniradja72@rediffmail.com some retained austenite, the amount increasing with the amount of alloying elements dissolved during austenitization. The larger the quantity of retained austenite contained in the steel after hardening the smaller is the increase in length or increase in volume. If the retained austenite content is sufficiently high, we generally obtain a reduction in volume [2].

Past experiences show that in surface hardening parts undergo volume and dimensional changes due to thermal fluctuations and phase transformations [3]. Dimensional changes can lead to excessive distortion in the components and results in excessive scrapage. Further, quench cracking can occur and the excessive grain growth in the region just below the hardened surface in the Gas carburizing and Induction hardening processes produces transformation stresses and thermal stresses (Thelning, 1984). These stresses cause shape and size distortion in the components. If the distortion is controlled within the tolerance limit, the post hardening processes can be eliminated by which cost and time can be saved. With this aim, experimental investigations have been carried out to study the thermal and metallurgical effects associated with Gas Carburizing and Induction hardening processes and the results are reported in this paper.

\section{SHAPE AND SIZE DISTORTION IN GAS CARBURIZING}

In case hardening process coping with deformation of materials is an important aspect. For long, considerable interest has been shown by researchers and practicing professionals to control if not totally overcome this problem. Normally, this problem of deformation is addressed by subjecting case hardened material to post-rectifying operations like straightening, machining, etc. [4].

The dimensional changes, which occur during case hardening, are governed by a wide variety of factors, as given below: 
The hardenability of the steel: More the hardenability and lesser the thickness of the material, more will be the volume increase.

Type of steel: It means the constituent alloying elements. The behaviour of $\mathrm{Cr}-\mathrm{Ni}$ steels, $\mathrm{Cr}-\mathrm{Ni}$-Mo steels and to some extent $\mathrm{Cr}-\mathrm{Mn}$ steels are similar in nature. On the other hand, Cr-Mo steels can exhibit some variations in behaviour as regards to change in shape.

Depth of case hardening: This factor is extremely difficult to assess because a considerable influence on the structure, properties, and thickness of the case hardened layer is exercised both by the carbon content in the surface layer and by the hardening temperature. However, it is obvious that the depth of case hardening influences the dimensional changes.

Method of hardening: In principle, direct hardening causes the least dimensional variations and double hardening causes the greatest changes. The deformation increases with the number of heating and cooling cycles.

Table 1. Gas Carburizing Operating Conditions

\begin{tabular}{|c|c|c|c|c|c|}
\hline S. No. & Factors & Notation & Level 1 & Level 2 & Level 3 \\
\hline 1 & Furnace Temperature & A & $870^{\circ} \mathrm{C}$ & $910^{\circ} \mathrm{C}$ & $940^{\circ} \mathrm{C}$ \\
\hline 2 & Quenching Time & B & 60 minutes & 90 minutes & 120 minutes \\
\hline 3 & Tempering Temperature & $\mathrm{C}$ & $150^{\circ} \mathrm{C}$ & $200^{\circ} \mathrm{C}$ & $250^{\circ} \mathrm{C}$ \\
\hline 4 & Tempering Time & $\mathrm{D}$ & 80 minutes & 100 minutes & 120 minutes \\
\hline 5 & Preheating & E & No preheating & $150^{\circ} \mathrm{C}$ & No preheating \\
\hline
\end{tabular}

Table 2. Gas Carburizing Test Results Materials: EN353 and EN 351 - (Run-Out)

\begin{tabular}{|c|c|c|c|c|c|c|c|c|c|c|c|}
\hline \multirow[t]{2}{*}{ S. No. } & \multirow[t]{2}{*}{$\mathbf{A}$} & \multirow[t]{2}{*}{ B } & \multirow[t]{2}{*}{$\mathrm{C}$} & \multirow[t]{2}{*}{ D } & \multirow[t]{2}{*}{$\mathbf{E}$} & \multicolumn{2}{|c|}{$\begin{array}{l}\text { Run-Out in Microns } \\
\text { for EN } 353\end{array}$} & \multicolumn{2}{|c|}{$\begin{array}{l}\text { Run-Out in Microns } \\
\text { for EN } 351\end{array}$} & \multicolumn{2}{|c|}{$\begin{array}{c}\text { S/N } \\
\text { for Run-Out }\end{array}$} \\
\hline & & & & & & $\mathbf{A Q}$ & AT & $\mathbf{A Q}$ & $\mathbf{A T}$ & EN 353 & EN 351 \\
\hline 1 & 870 & 60 & 150 & 80 & NO & 70 & 70 & 110 & 110 & 23.098 & 19.172 \\
\hline 2 & 870 & 60 & 200 & 100 & 150 & 40 & 40 & 60 & 72 & 27.958 & 23.573 \\
\hline 3 & 870 & 60 & 250 & 120 & $\mathrm{NO}$ & 60 & 40 & 50 & 50 & 25.850 & 26.020 \\
\hline 4 & 870 & 90 & 150 & 100 & 150 & 24 & 100 & 30 & 36 & 22.767 & 29.593 \\
\hline 5 & 870 & 90 & 200 & 120 & $\mathrm{NO}$ & 24 & 90 & 50 & 54 & 23.627 & 25.673 \\
\hline 6 & 870 & 90 & 250 & 80 & $\mathrm{NO}$ & 78 & 70 & 100 & 110 & 22.602 & 19.566 \\
\hline 7 & 870 & 120 & 150 & 120 & $\mathrm{NO}$ & 102 & 80 & 120 & 105 & 20.756 & 18.957 \\
\hline 8 & 870 & 120 & 200 & 80 & NO & 80 & 110 & 90 & 89 & 20.338 & 20.963 \\
\hline 9 & 870 & 120 & 250 & 100 & 150 & 108 & 60 & 110 & 105 & 21.173 & 19.369 \\
\hline 10 & 910 & 60 & 150 & 80 & 150 & 82 & 50 & 120 & 110 & 23.361 & 18.777 \\
\hline 11 & 910 & 60 & 200 & 100 & $\mathrm{NO}$ & 28 & 30 & 60 & 65 & 30.746 & 24.075 \\
\hline 12 & 910 & 60 & 250 & 120 & NO & 30 & 60 & 70 & 72 & 26.478 & 22.973 \\
\hline 13 & 910 & 90 & 150 & 100 & $\mathrm{NO}$ & 60 & 100 & 40 & 44 & 21.674 & 27.525 \\
\hline 14 & 910 & 90 & 200 & 120 & $\mathrm{NO}$ & 32 & 60 & 60 & 68 & 26.360 & 23.859 \\
\hline 15 & 910 & 90 & 250 & 80 & 150 & 60 & 100 & 40 & 44 & 21.674 & 27.525 \\
\hline 16 & 910 & 120 & 150 & 120 & NO & 50 & 90 & 60 & 67 & 22.757 & 23.931 \\
\hline 17 & 910 & 120 & 200 & 80 & 150 & 62 & 45 & 100 & 98 & 25.324 & 20.086 \\
\hline 18 & 910 & 120 & 250 & 100 & $\mathrm{NO}$ & 60 & 55 & 70 & 59 & 24.798 & 23.777 \\
\hline 19 & 940 & 60 & 150 & 80 & NO & 20 & 40 & 40 & 36 & 30 & 28.392 \\
\hline 20 & 940 & 60 & 200 & 100 & NO & 100 & 35 & 90 & 85 & 22.508 & 21.156 \\
\hline 21 & 940 & 60 & 250 & 120 & 150 & 110 & 72 & 82 & 87 & 20.633 & 21.459 \\
\hline 22 & 940 & 90 & 150 & 100 & $\mathrm{NO}$ & 32 & 24 & 40 & 44 & 30.969 & 27.525 \\
\hline 23 & 940 & 90 & 200 & 120 & 150 & 22 & 20 & 25 & 36 & 33.545 & 30.175 \\
\hline 24 & 940 & 90 & 250 & 80 & NO & 38 & 70 & 80 & 72 & 24.986 & 22.371 \\
\hline 25 & 940 & 120 & 150 & 120 & 150 & 30 & 44 & 60 & 56 & 28.483 & 24.726 \\
\hline 26 & 940 & 120 & 200 & 80 & $\mathrm{NO}$ & 30 & 44 & 40 & 47 & 28.483 & 27.202 \\
\hline 27 & 940 & 120 & 250 & 100 & NO & 100 & 80 & 100 & 110 & 20.861 & 19.566 \\
\hline
\end{tabular}


Table 3. Gas Carburizing Test Results Materials: EN353 and EN 351 (Helix Variations - Left)

\begin{tabular}{|c|c|c|c|c|c|c|c|c|c|c|c|}
\hline \multirow{3}{*}{ S. No. } & \multirow{3}{*}{$\mathbf{A}$} & \multirow{3}{*}{ B } & \multirow{3}{*}{$\mathbf{C}$} & \multirow{3}{*}{$\mathbf{D}$} & \multirow{3}{*}{$\mathbf{E}$} & \multicolumn{4}{|c|}{ Left - Helix Variations in Microns } & \multirow{2}{*}{\multicolumn{2}{|c|}{$\stackrel{S / N}{\text { for Helix-Variation (Left) }}$}} \\
\hline & & & & & & \multicolumn{2}{|c|}{ EN 353} & \multicolumn{2}{|c|}{ EN 351} & & \\
\hline & & & & & & BHT & AHT & BHT & AHT & EN 353 & EN 351 \\
\hline 1 & 870 & 60 & 150 & 80 & NO & 13.2 & 40.2 & 40.2 & 17.5 & 30.481 & 30.172 \\
\hline 2 & 870 & 60 & 200 & 100 & 150 & 13.2 & 15.2 & 15.6 & 16.2 & 36.932 & 35.970 \\
\hline 3 & 870 & 60 & 250 & 120 & NO & 70.2 & 48.2 & 60.1 & 62.2 & 24.406 & 24.270 \\
\hline 4 & 870 & 90 & 150 & 100 & 150 & 0.7 & 52.6 & 52.3 & 0.7 & 28.589 & 28.639 \\
\hline 5 & 870 & 90 & 200 & 120 & NO & 13.2 & 12.4 & 12.4 & 12 & 37.851 & 38.271 \\
\hline 6 & 870 & 90 & 250 & 80 & NO & 13.2 & 38.4 & 37.8 & 15.2 & 30.838 & 30.809 \\
\hline 7 & 870 & 120 & 150 & 120 & NO & 40 & 30.4 & 30.2 & 46.0 & 28.989 & 28.198 \\
\hline 8 & 870 & 120 & 200 & 80 & NO & 7.2 & 24.2 & 28.4 & 7.2 & 34.965 & 33.673 \\
\hline 9 & 870 & 120 & 250 & 100 & 150 & 24.1 & 22.1 & 19.1 & 28.2 & 32.719 & 32.365 \\
\hline 10 & 910 & 60 & 150 & 80 & 150 & 44.4 & 1.5 & 7.9 & 44.0 & 30.057 & 30.003 \\
\hline 11 & 910 & 60 & 200 & 100 & $\mathrm{NO}$ & 4.2 & 72 & 82 & 6.0 & 25.848 & 24.710 \\
\hline 12 & 910 & 60 & 250 & 120 & $\mathrm{NO}$ & 46 & 0 & 2.4 & 44 & 29.755 & 30.128 \\
\hline 13 & 910 & 90 & 150 & 100 & $\mathrm{NO}$ & 11.8 & 12.5 & 14.6 & 12.4 & 38.304 & 37.364 \\
\hline 14 & 910 & 90 & 200 & 120 & $\mathrm{NO}$ & 44.2 & 34.6 & 40 & 48.4 & 28.026 & 27.052 \\
\hline 15 & 910 & 90 & 250 & 80 & 150 & 13.1 & 36.7 & 36.7 & 16.2 & 31.196 & 30.943 \\
\hline 16 & 910 & 120 & 150 & 120 & NO & 27 & 36 & 37.2 & 29.3 & 29.946 & 29.503 \\
\hline 17 & 910 & 120 & 200 & 80 & 150 & 0.9 & 42.5 & 42.3 & 1.2 & 30.440 & 30.48 \\
\hline 18 & 910 & 120 & 250 & 100 & $\mathrm{NO}$ & 42.7 & 35.5 & 37.7 & 40 & 28.119 & 28.208 \\
\hline 19 & 940 & 60 & 150 & 80 & $\mathrm{NO}$ & 14.6 & 33.2 & 34.8 & 14.7 & 31.819 & 31.465 \\
\hline 20 & 940 & 60 & 200 & 100 & NO & 24.8 & 48.2 & 49.2 & 28.2 & 28.329 & 27.937 \\
\hline 21 & 940 & 60 & 250 & 120 & 150 & 46 & 17.1 & 10.2 & 18.3 & 29.193 & 36.586 \\
\hline 22 & 940 & 90 & 150 & 100 & NO & 44 & 32.2 & 34.2 & 44.2 & 28.278 & 28.064 \\
\hline 23 & 940 & 90 & 200 & 120 & 150 & 2.8 & 0.7 & 1.4 & 4.5 & 53.803 & 49.544 \\
\hline 24 & 940 & 90 & 250 & 80 & NO & 54.4 & 24.2 & 27.2 & 56.2 & 27.514 & 27.101 \\
\hline 25 & 940 & 120 & 150 & 120 & 150 & 0.82 & 22.5 & 27.2 & 1.9 & 35.960 & 34.297 \\
\hline 26 & 940 & 120 & 200 & 80 & NO & 40.1 & 50 & 56 & 36.2 & 26.873 & 26.530 \\
\hline 27 & 940 & 120 & 250 & 100 & $\mathrm{NO}$ & 1.8 & 15.6 & 17.4 & 1.9 & 39.090 & 38.147 \\
\hline
\end{tabular}

Material dimensions: A clear tendency towards shrinkage in the diameter of gears has been observed in connexion with small or moderate dimensional or material thicknesses. As the dimensions of gears and rings increase, the shrinkage decreases, and at a certain dimension there is an increase in the diameter.

The main problem in the Gas carburized components is shape and size distortion. Shape distortion can be reduced by proper stress relieving between machining as they are mostly due to residual stresses. Whereas, size distortion is due to structural transformations in steel. When austenite transforms into martensite there is an expansion in volume. While tempering there is a contraction due to the formation of carbides. The presence of retained austenite and its change during tempering introduces complex overall changes in size. Many literatures indicate that the following are some of the reasons for distortion.

* Due to rapid heating

* Methods of stacking or fixturing of parts

* Increase in grain growth with increase in case depth

* Severity of quenching

One of the objectives of the present work is to minimizing the distortion level (in the present case, run-out and helix-variations) in pinion made of EN 353 and EN 351 material (used in power steering assembly) with optimum case depth and surface hardness value. Taguchi's mixed level series [5]. Design of Experiment is adopted to arrive at the level of process parameters, which will minimize the distortion in heat treated material [6]. 
Table 4. Gas Carburizing Test Results Materials: EN353 and EN 351 - (Helix Variations - Right)

\begin{tabular}{|c|c|c|c|c|c|c|c|c|c|c|c|}
\hline \multirow{3}{*}{ S. No. } & \multirow{3}{*}{$\mathbf{A}$} & \multirow{3}{*}{ B } & \multirow{3}{*}{$\mathbf{C}$} & \multirow{3}{*}{ D } & \multirow{3}{*}{$\mathbf{E}$} & \multicolumn{4}{|c|}{ Right - Helix Variations in Microns } & \multirow{2}{*}{\multicolumn{2}{|c|}{$\begin{array}{c}\mathrm{S} / \mathrm{N} \\
\text { for Helix-Variation (Right }\end{array}$}} \\
\hline & & & & & & \multicolumn{2}{|c|}{ EN 353} & \multicolumn{2}{|c|}{ EN 351} & & \\
\hline & & & & & & BHT & AHT & BHT & AHT & EN 353 & EN 351 \\
\hline 1 & 870 & 60 & 150 & 80 & NO & 45.2 & 50.15 & 69.4 & 43.5 & 26.422 & 24.743 \\
\hline 2 & 870 & 60 & 200 & 100 & 150 & 58.2 & 48.2 & 71.4 & 44.3 & 25.443 & 24.521 \\
\hline 3 & 870 & 60 & 250 & 120 & NO & 68.4 & 112.4 & 67.2 & 110.2 & 20.626 & 20.793 \\
\hline 4 & 870 & 90 & 150 & 100 & 150 & 26.8 & 60 & 24.4 & 62 & 26.657 & 26.537 \\
\hline 5 & 870 & 90 & 200 & 120 & $\mathrm{NO}$ & 46.2 & 4.2 & 44.4 & 5.5 & 29.681 & 29.996 \\
\hline 6 & 870 & 90 & 250 & 80 & NO & 29.4 & 82 & 29.3 & 80.2 & 24.208 & 24.382 \\
\hline 7 & 870 & 120 & 150 & 120 & NO & 104.3 & 44 & 105.4 & 42.2 & 21.933 & 21.907 \\
\hline 8 & 870 & 120 & 200 & 80 & NO & 34.2 & 25.2 & 34.5 & 24.4 & 30.446 & 30.492 \\
\hline 9 & 870 & 120 & 250 & 100 & 150 & 8.1 & 72.4 & 9.2 & 72.3 & 25.761 & 25.757 \\
\hline 10 & 910 & 60 & 150 & 80 & 150 & 65.2 & 50.1 & 72.1 & 50.3 & 24.710 & 24.129 \\
\hline 11 & 910 & 60 & 200 & 100 & NO & 46.2 & 89.2 & 48.2 & 85.4 & 22.970 & 23.180 \\
\hline 12 & 910 & 60 & 250 & 120 & NO & 38.41 & 2.1 & 39.2 & 0.5 & 31.308 & 31.143 \\
\hline 13 & 910 & 90 & 150 & 100 & $\mathrm{NO}$ & 34.3 & 24.4 & 37.2 & 20.4 & 30.526 & 30.457 \\
\hline 14 & 910 & 90 & 200 & 120 & $\mathrm{NO}$ & 42 & 40.8 & 41 & 41.4 & 27.659 & 27.701 \\
\hline 15 & 910 & 90 & 250 & 80 & 150 & 32.2 & 42.4 & 32.2 & 46.1 & 28.485 & 28.010 \\
\hline 16 & 910 & 120 & 150 & 120 & NO & 52.4 & 32.4 & 54.2 & 37.2 & 27.217 & 26.653 \\
\hline 17 & 910 & 120 & 200 & 80 & 150 & 17.6 & 51.2 & 17.2 & 54.4 & 28.339 & 27.884 \\
\hline 18 & 910 & 120 & 250 & 100 & NO & 39.2 & 24.5 & 40.1 & 24.4 & 29.712 & 29.579 \\
\hline 19 & 940 & 60 & 150 & 80 & $\mathrm{NO}$ & 28.4 & 23.5 & 29.4 & 28.4 & 31.678 & 30.780 \\
\hline 20 & 940 & 60 & 200 & 100 & $\mathrm{NO}$ & 38.2 & 31.5 & 37.2 & 34.6 & 29.116 & 28.892 \\
\hline 21 & 940 & 60 & 250 & 120 & 150 & 10.2 & 32.4 & 12.4 & 31.3 & 32.388 & 32.466 \\
\hline 22 & 940 & 90 & 150 & 100 & NO & 26.2 & 44.5 & 27.2 & 44.4 & 28.750 & 28.678 \\
\hline 23 & 940 & 90 & 200 & 120 & 150 & 0.9 & 20.4 & 0.5 & 20.4 & 36.809 & 36.815 \\
\hline 24 & 940 & 90 & 250 & 80 & NO & 54.2 & 40.2 & 54.6 & 52 & 26.426 & 25.462 \\
\hline 25 & 940 & 120 & 150 & 120 & 150 & 6.2 & 35.4 & 7.2 & 35.4 & 31.899 & 31.854 \\
\hline 26 & 940 & 120 & 200 & 80 & NO & 42.4 & 58.2 & 42.1 & 58.6 & 25.862 & 25.844 \\
\hline 27 & 940 & 120 & 250 & 100 & $\mathrm{NO}$ & 21.2 & 6.3 & 20.4 & 4.8 & 36.116 & 36.583 \\
\hline
\end{tabular}

The significance in this study is the three stages of carburizing (Pre carburizing, Carburizing and Post carburizing) are considered for optimization [7]. An orthogonal array and ANOVA are employed to investigate the influence of major process variables on Distortion level, Surface hardness and Case depth. Optimum conditions have been arrived at by applying high penetration depth, high hardness and low distortions are better as the strategies. Response graph and Signal to Noise ratio methods are followed to predict the optimum results and the results are compared.

The conditions underwhich the gas carburizing experiments have been carried out are given in Table 1. The run-out of the pinion after quenching (AQ) and after tempering (AT) of the pinion materials are measured using mechanical dial gauge. The left and right helix variations before heat treatment (BHT) and after heat treatment (AHT) of the pinion materials are measured using a gear tester. The measured values are tabulated in Tables 2-4.

The experiments have been conducted based on L27 orthogonal array system proposed in Taguchis' Mixed Level Series of DOE with interactions as given below:

i) Furnace Temperature vs Quenching Time (AxB)

ii) Furnace Temperature vs Tempering Temperature $(\mathrm{AxC})$

\subsection{Response Graph Method}

Response graphs are shown in Figs. (1a-e, 2a-e) drawn using the values in Tables 5-7. 
Table 5. Average Effect of Process Variables on Run-Out

\begin{tabular}{|c|c|c|c|c|c|c|}
\hline \multirow[t]{2}{*}{ Variables } & \multicolumn{2}{|c|}{$\begin{array}{c}\text { Level } 1 \\
\text { Run-Out }\end{array}$} & \multicolumn{2}{|c|}{$\begin{array}{c}\text { Level } 2 \\
\text { Run-Out }\end{array}$} & \multicolumn{2}{|c|}{$\begin{array}{c}\text { Level } 3 \\
\text { Run-Out }\end{array}$} \\
\hline & EN 353 & EN 351 & EN 353 & EN 351 & EN 353 & EN 351 \\
\hline Furnace temperature & 72.111 & 80.611 & 58.56 & 69.28 & 50.6111 & 61.9444 \\
\hline Quenching Time & 57.167 & 65.056 & 55.778 & 54.056 & 67.11 & 82.56 \\
\hline Tempering Temperature & 59.33 & 68.22 & 49.56 & 66.06 & 69.5 & 78.39 \\
\hline Tempering Time & 62.17 & 68.78 & 59.78 & 67.78 & 56.44 & 65.11 \\
\hline Preheating & 65.06 & 81.94 & 59.39 & 70.61 & - & - \\
\hline
\end{tabular}

Table 6. Average Effect of Process Variables on Left -Helix Variations

\begin{tabular}{|c|c|c|c|c|c|c|}
\hline \multirow[t]{2}{*}{ Variables } & \multicolumn{2}{|c|}{$\begin{array}{c}\text { Level } 1 \\
\text { Left - Helix }\end{array}$} & \multicolumn{2}{|c|}{$\begin{array}{c}\text { Level } 2 \\
\text { Left - Helix }\end{array}$} & \multicolumn{2}{|c|}{$\begin{array}{c}\text { Level } 3 \\
\text { Left - Helix }\end{array}$} \\
\hline & EN 353 & EN 351 & EN 353 & EN 351 & EN 353 & EN 351 \\
\hline Furnace temperature & 26.5944 & 27.85 & 28.089 & 30.128 & 25.279 & 25.761 \\
\hline Quenching Time & 30.68 & 30.75 & 24.5389 & 25.9111 & 25.746 & 27.078 \\
\hline Tempering Temperature & 25.423 & 27.183 & 25.022 & 27.067 & 30.517 & 29.489 \\
\hline Tempering Time & 27.4 & 28.8722 & 26.289 & 27.772 & 27.34 & 27.0944 \\
\hline Preheating & 27.267 & 29.039 & 19.829 & 19.106 & - & - \\
\hline
\end{tabular}

Table 7. Average Effect of Process Variables on Right -Helix Variations

\begin{tabular}{|c|c|c|c|c|c|c|}
\hline \multirow[t]{2}{*}{ Variables } & \multicolumn{2}{|c|}{$\begin{array}{c}\text { Level } 1 \\
\text { Right - Helix }\end{array}$} & \multicolumn{2}{|c|}{$\begin{array}{c}\text { Level } 2 \\
\text { Right - Helix }\end{array}$} & \multicolumn{2}{|c|}{$\begin{array}{c}\text { Level } 3 \\
\text { Right - Helix }\end{array}$} \\
\hline & EN 353 & EN 351 & EN 353 & EN 351 & EN 353 & EN 351 \\
\hline Furnace temperature & 51.075 & 52.21111 & 40.25611 & 41.19444 & 29.35 & 30.05 \\
\hline Quenching Time & 46.99778 & 48.61111 & 36.17222 & 37.95556 & 37.5111 & 38 \\
\hline Tempering Temperature & 41.8583 & 43.9056 & 38.6 & 40.19444 & 39.77833 & 40.35556 \\
\hline Tempering Time & 42.875 & 45.48333 & 38.85555 & 39.32777 & 38.50611 & 38.64444 \\
\hline Preheating & 35.67556 & 36.85556 & 35.43889 & 36.83889 & - & - \\
\hline
\end{tabular}

\subsubsection{Influence of Main Variables on Run-Out}

ANOVA analysis is carried out to determine the influence of main variables on run-out and also to determine the percentage contributions of each factor. Table 8 shows the results of percentage contribution of each variable for run-out.

\subsubsection{Model Calculation for EN 351}

Correction factor, C.F,

$$
\begin{aligned}
& =\left[\sum y i\right]^{2} / \text { Number of Experiment } \\
& =[110+66+\ldots . .105]^{2} / 27 \\
& =119533.77
\end{aligned}
$$

Total sum of squares, SST

$$
\begin{aligned}
& =\sum y i^{2}-\text { C.F } \\
& =129254-119533.77
\end{aligned}
$$

$$
=9720.23
$$

Sum of Squares of Factors,

Variable A, SSA

$$
=\left[\sum y 1^{2} / 9+\sum y 2^{2} / 9+\sum y 3^{2} / 9\right]-
$$

C.F

$$
\begin{aligned}
& =[51604.09+36992.11+32160.44]-\mathrm{C} . \mathrm{F} \\
& =120757.25-119533.77 \\
& =1223.48
\end{aligned}
$$

Percentage contribution of each factor, A

$$
\begin{aligned}
& =(\mathrm{SSA} / \mathrm{SST}) * 100 \\
& =(1223.48 / 9720.2) * 100 \\
& =12.58 \%
\end{aligned}
$$

In the same way the percentage contribution of other variables are calculated. 
Total contribution of factors

$$
\begin{aligned}
& =(A+B+C+D+A x B+A x C) \\
& =88.19 \%
\end{aligned}
$$

$\therefore$ Error

$$
=11.81 \%
$$

(a)

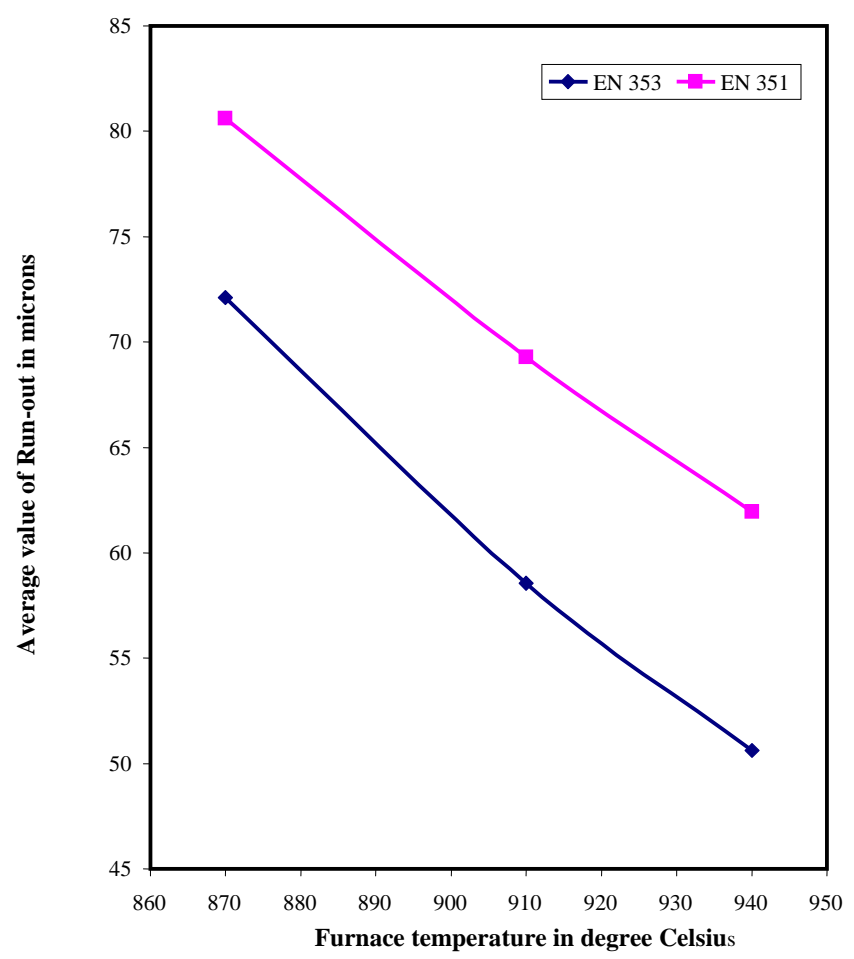

(b)

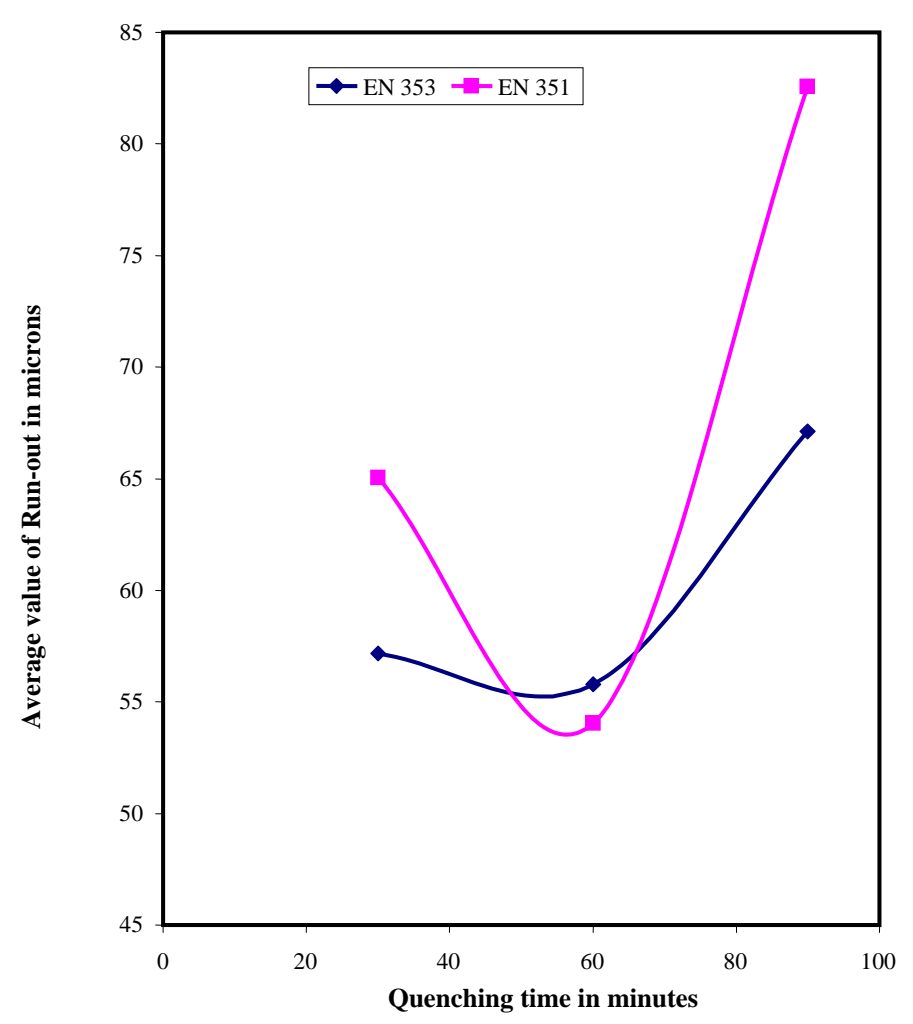

(Fig. 1) contd.....

(c)

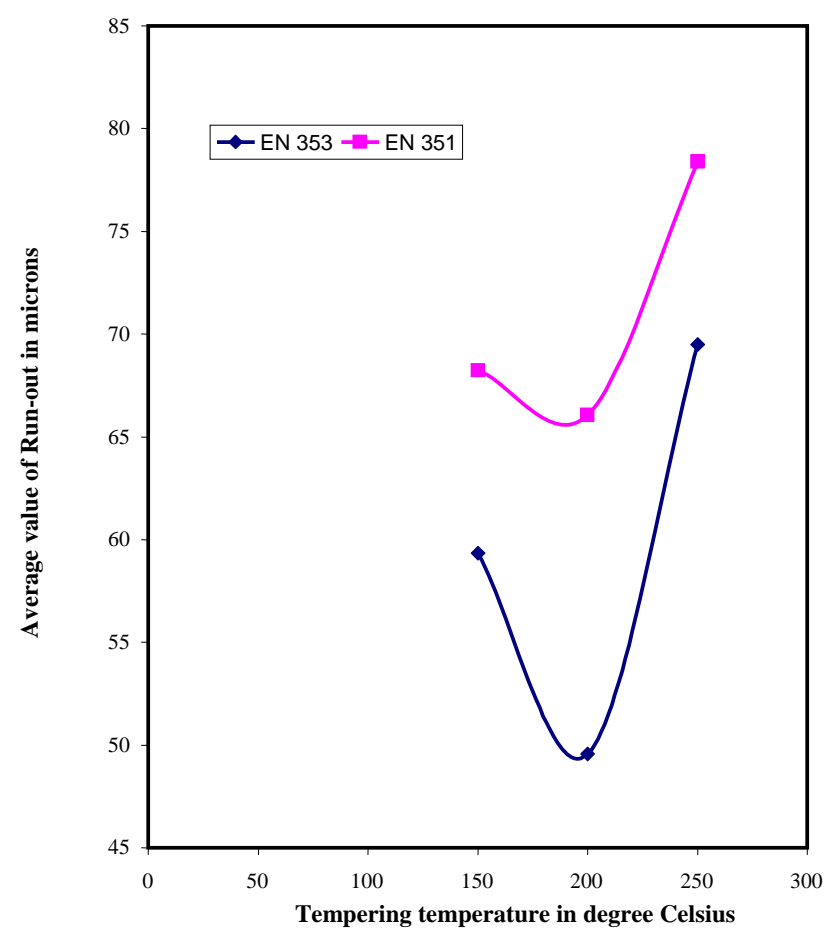

(d)

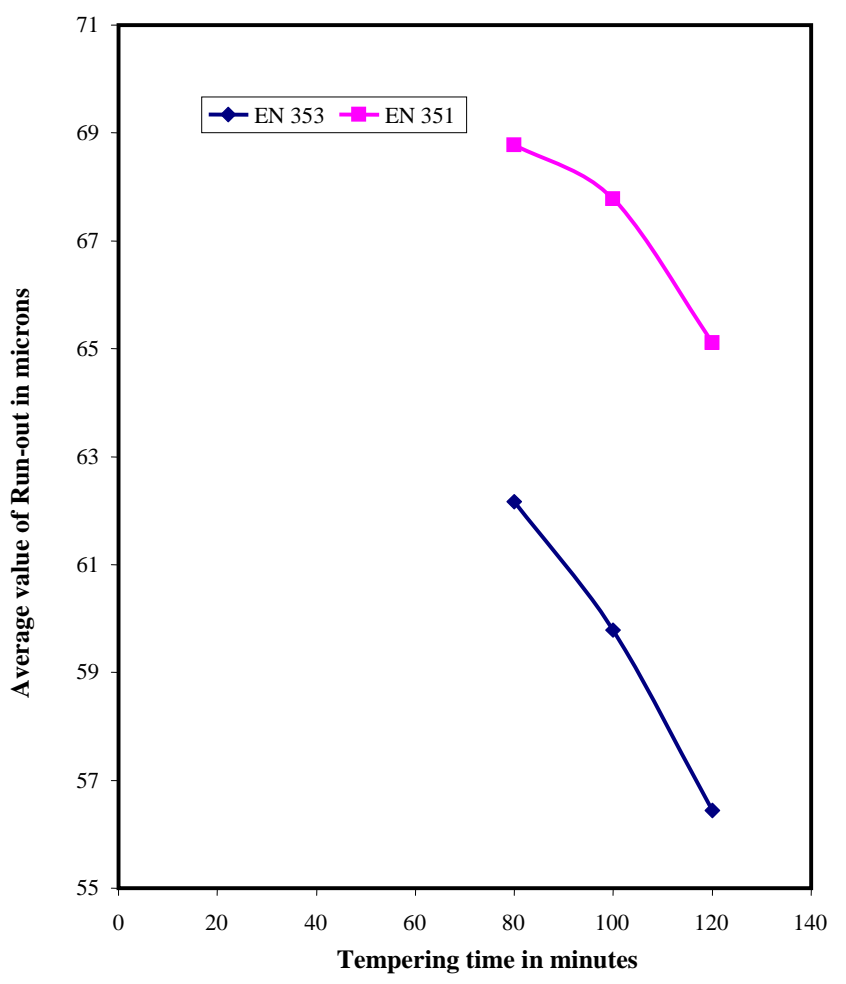


(Fig. 1) contd.....

(e)

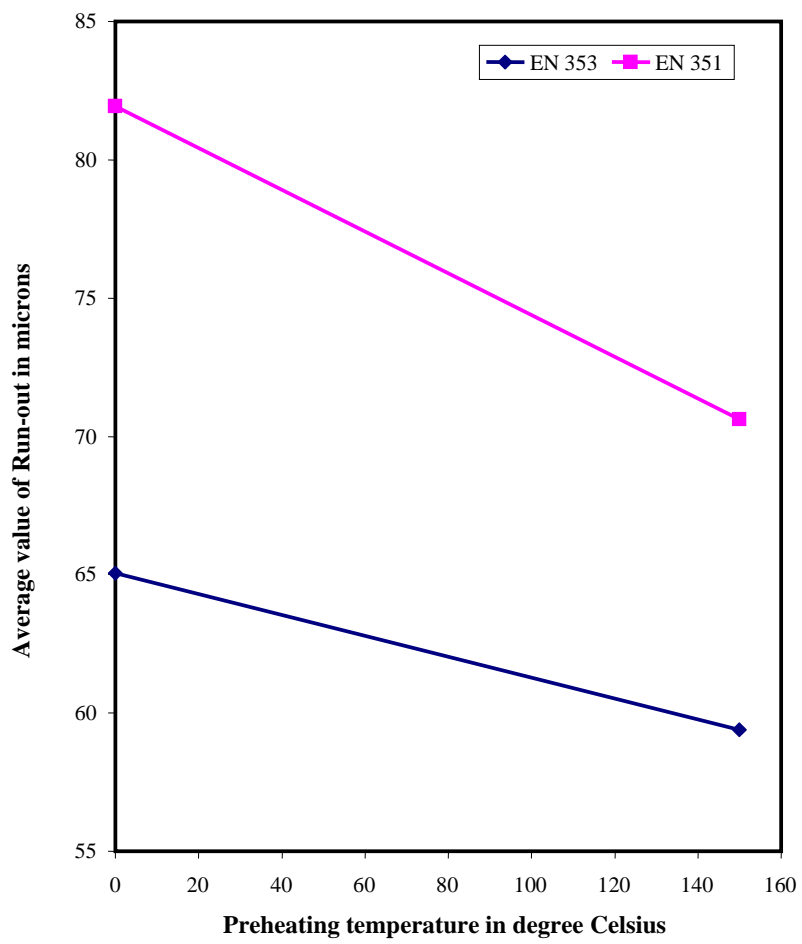

Fig. (1). (a-e) Process variables $v s$ run-out.

Table 8. Percentage Contribution of Each Variable on RunOut

\begin{tabular}{|l|c|c|}
\hline \multirow{2}{*}{ Variables } & \multicolumn{2}{c|}{ Run-Out } \\
\cline { 2 - 3 } & EN 353 & EN 351 \\
\hline \hline Furnace temperature & $\mathbf{1 4 . 5 3 \%}$ & $\mathbf{1 2 . 5 8 \%}$ \\
\hline Quenching Time & $\mathbf{1 2 . 8 2 \%}$ & $\mathbf{1 1 . 8 4 \%}$ \\
\hline Tempering Temperature & $\mathbf{6 . 1 2} \%$ & $\mathbf{5 . 1 9 \%}$ \\
\hline Tempering Time & $\mathbf{7 . 9 4 \%}$ & $\mathbf{7 . 9 8 \%}$ \\
\hline Preheating & $\mathbf{1 4 . 1 9 \%}$ & $\mathbf{1 5 . 8 8 \%}$ \\
\hline Furnace Temperature and Quenching time & $\mathbf{2 6 . 4 3 \%}$ & $\mathbf{2 7 . 5 8 \%}$ \\
\hline Furnace Temperature and Tempering Temperature & $\mathbf{5 . 9 8 \%}$ & $\mathbf{7 . 1 4 \%}$ \\
\hline Error & $\mathbf{1 1 . 9 9 \%}$ & $\mathbf{1 1 . 8 1 \%}$ \\
\hline
\end{tabular}

Optimum set of variables for run-out is found by adopting the Lower is better strategy. The results are given in Table 9.

\subsection{Prediction of Mean Response (Run-Out)}

From Taguchis' methodology, equation (1) can be used to predict the run-out obtainable.

$\beta=\mathrm{T}+\left(\mathrm{RA}_{\mathrm{opt}}-\mathrm{T}\right)+\left(\mathrm{RB}_{\mathrm{opt}}-\mathrm{T}\right)+\left(\mathrm{RC}_{\mathrm{opt}}-\mathrm{T}\right)+\left(\mathrm{RD}_{\mathrm{opt}}-\mathrm{T}\right)+$ $\left(\mathrm{RE}_{\mathrm{opt}}-\mathrm{T}\right)$

where,

$\beta$-predicted mean response.
T-mean of all observed run-out values;

$\mathrm{RA}_{\text {opt, }} \mathrm{RB}$ opt, $\mathrm{RC}_{\text {opt, }} \mathrm{RD}$ opt, and $\mathrm{RE}_{\text {opt }}-$ Runout values obtained at optimum process variable conditions.

Table 9. Optimum Conditions for Run-Out for EN 353 and EN 351

\begin{tabular}{|c|c|c|}
\hline \multirow{2}{*}{ Variables } & \multicolumn{2}{|c|}{ Run-Out } \\
\hline & EN 353 & EN 351 \\
\hline Furnace temperature & $940^{\circ} \mathrm{C}$ & $940^{\circ} \mathrm{C}$ \\
\hline Quenching Time & 90 minutes & 90 minutes \\
\hline Tempering Temperature & $200^{\circ} \mathrm{C}$ & $200^{\circ} \mathrm{C}$ \\
\hline Tempering Time & 120 minutes & 120 minutes \\
\hline Preheating & $150^{\circ} \mathrm{C}$ & $150^{\circ} \mathrm{C}$ \\
\hline
\end{tabular}

\subsubsection{Model Calculation for EN 353 Material}

$\mathrm{T}=\{(110+66+50+33+52+105+112.5+89.5+107.5+115+62.5$

$+71+42+64+42+63.5+99+64.5+38+87.5+84.5+42+30.5+76$

$+58+43.5+105) / 27\} \quad$ (Table 2)

$\mathrm{T}=70.888$

$\mathrm{RA}_{\mathrm{opt}}=61.94$

$\mathrm{RB}_{\mathrm{opt}}=54.056 \quad$ from Table $\mathbf{5}$

$\mathrm{RC}_{\mathrm{opt}}=66.06$

$\mathrm{RD}_{\text {opt }}=65.11$

$\left.\mathrm{RE}_{\text {opt }}=70.61\right)$

$\beta$ (Run-out $)=70.888+(61.94-70.888)+(54.056-70.888)$ $+(66.06-70.888)+(65.11-70.888)+(70.61-70.888)=$ 34.224 microns.

Similarly, for EN 353 the predicted mean response, $\beta=$ 33.998 microns.

Optimum Run-out value, for EN 353 - 33.998 microns and EN 351 - $\mathbf{3 4 . 2 2 4}$ microns.

\subsubsection{Influence of Main Variables on Helix-Variations}

ANOVA analysis is carried out to determine the influence of main variables on helix variations (left) and also to determine the percentage contribution of each variable. Table 10 shows the results of percentage contribution of each factor for helix-variation (Left).

\section{Model Calculation for EN 353}

Correction factor, C.F

$$
\begin{aligned}
& =\left[\sum y i\right]^{2} / \text { Number of Experiment } \\
& =[26.7+14.2+\ldots .8 .7]^{2} / 27 \\
& =19664.64
\end{aligned}
$$

Total sum of squares, SST

$$
\begin{aligned}
& =\sum y i^{2}-\text { C.F } \\
& =23936.44-19664.64 \\
& =4271.8
\end{aligned}
$$


Sum of Squares of Factors,

Variable, A SSA

$$
=\left[\sum y 1^{2} / 9+\sum y 2^{2} / 9+\sum y 3^{2} / 9\right]-
$$

C.F

$$
\begin{aligned}
& =[6365.38+7100.87+6342.20]-\text { C.F } \\
& =19808.45-19664.64 \\
& =143.81
\end{aligned}
$$

Percentage contribution of each factor, A

$$
\begin{aligned}
& =(\mathrm{SSA} / \mathrm{SST}) * 100 \\
& =(143.81 / 4271.8) * 100 \\
& =3.36 \%
\end{aligned}
$$

In the same way the percentage contribution of other variables are calculated.

Total contribution of factors

$$
=(\mathrm{A}+\mathrm{B}+\mathrm{C}+\mathrm{D}+\mathrm{E}+\mathrm{AxB}+\mathrm{AxC})=82.43 \%
$$

$\therefore$ Error $\quad=17.6 \%$

Table 10. Percentage Contribution of Each Variable on Helix Variation (Left)

\begin{tabular}{|l|c|c|}
\hline \multirow{2}{*}{\multicolumn{2}{|c|}{ Variables }} & \multicolumn{2}{c|}{$\begin{array}{c}\text { Helix Variation } \\
\text { (Left) }\end{array}$} \\
\cline { 2 - 3 } & EN 353 & EN 351 \\
\hline \hline Furnace temperature & $\mathbf{4 . 9 8 \%}$ & $\mathbf{3 . 8 0 \%}$ \\
\hline Quenching Time & $\mathbf{8 . 1 4 \%}$ & $\mathbf{3 . 1 5 \%}$ \\
\hline Tempering Temperature & $\mathbf{8 . 1 4 \%}$ & $\mathbf{1 0 . 8 9 \%}$ \\
\hline Tempering Time & $\mathbf{1 1 . 8 2 \%}$ & $\mathbf{1 5 . 2 1 \%}$ \\
\hline Preheating & $\mathbf{1 7 . 1 4 \%}$ & $\mathbf{1 7 . 1 5 \%}$ \\
\hline Furnace Temperature and Quenching time & $\mathbf{2 7 . 1 2 \%}$ & $\mathbf{2 8 . 1 3 \%}$ \\
\hline Furnace Temperature and Tempering Temperature & $\mathbf{9 . 8 4 \%}$ & $\mathbf{6 . 2 1 \%}$ \\
\hline Error & $\mathbf{1 7 . 6 \%}$ & $\mathbf{1 5 . 1 1 \%}$ \\
\hline
\end{tabular}

Optimum set of variables for helix-variations (left) are found by adopting the Lower is better strategy. The results are given in Table 9.

\subsubsection{Prediction of Mean Response (Helix Variations-Left)}

From Taguchis' methodology, equation (2) can be used to predict the Helix variations (Left) obtainable,

$\beta=\mathrm{T}+\left(\mathrm{LA}_{\mathrm{opt}}-\mathrm{T}\right)+\left(\mathrm{LB}_{\mathrm{opt}}-\mathrm{T}\right)+\left(\mathrm{LC}_{\mathrm{opt}}-\mathrm{T}\right)+\left(\mathrm{LD}_{\mathrm{opt}}-\mathrm{T}\right)+$ $\left(\mathrm{LE}_{\mathrm{opt}}-\mathrm{T}\right)$

where,

$\beta$-predicted mean response
T-mean of all observed Helix- variations (Left) values; LA opt, LB opt, LC opt, LD opt, and LE opt - helix variations (Left) values obtained at optimum process variable condition.

\subsubsection{Model Calculation for EN 353 Material}

$\mathrm{T}=\{(26.7+14.2+59.2+26.65+12.8+25.8+35.2+15.7+23.1+$ $22.95+38.1+23+12.15+39.4+24.9+31.5+21.7+39.1+23.9+36$ $.5+31.55+38.1+1.75+39.3+11.66+45.05+8.7) / 27\} \quad$ (from Table 3)

$\mathrm{T}=26.98$

$$
\left.\begin{array}{l}
\mathrm{LA}_{\text {opt }}=25.279 \\
\mathrm{LB}_{\text {opt }}=24.5389 \\
\mathrm{LC}_{\text {opt }}=25.022 \\
\mathrm{LD}_{\text {opt }}=27.34 \\
\mathrm{LE}_{\text {opt }}=19.829
\end{array}\right\}
$$

(From Table 6)

$\beta$ (helix variations -left) $=26.98+(25.279-26.98)+$ $(24.5389-26.98)+(25.022-26.98)+(27.34-26.98)+$ $(27.34-26.98)=21.5999$ microns

Similarly for EN 353 the predicted mean response $\beta=$ 21.5999 microns.

Predicted mean difference is given by, EN 353 - 21.5999 microns and EN 351 - $\mathbf{1 3 . 7 9 0}$ microns.

(a)

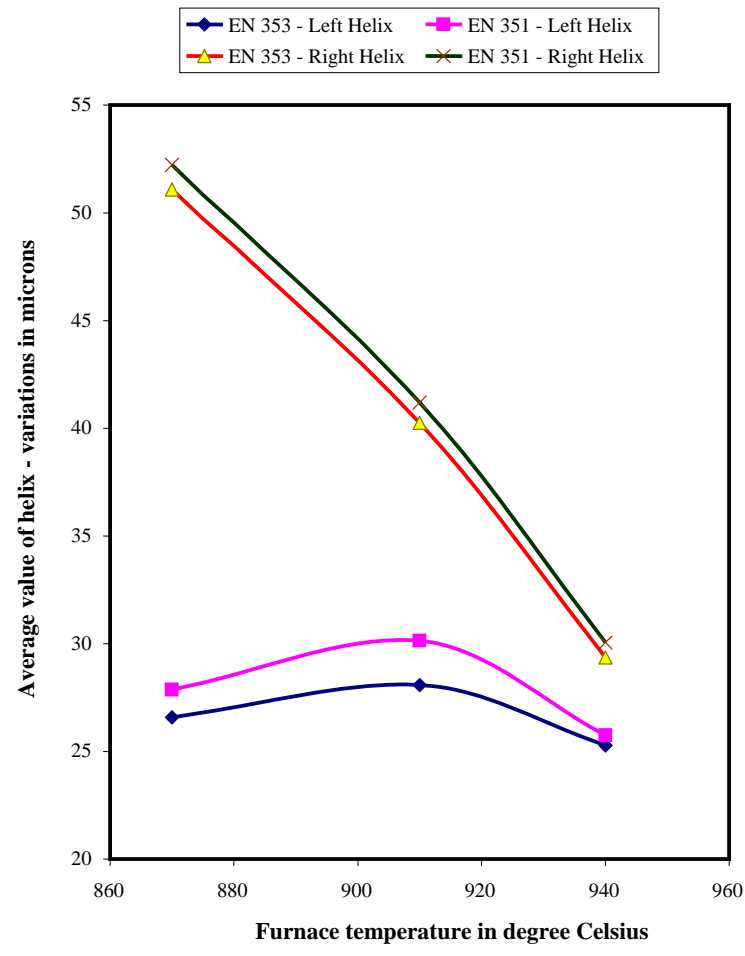


(Fig. 2) contd.....

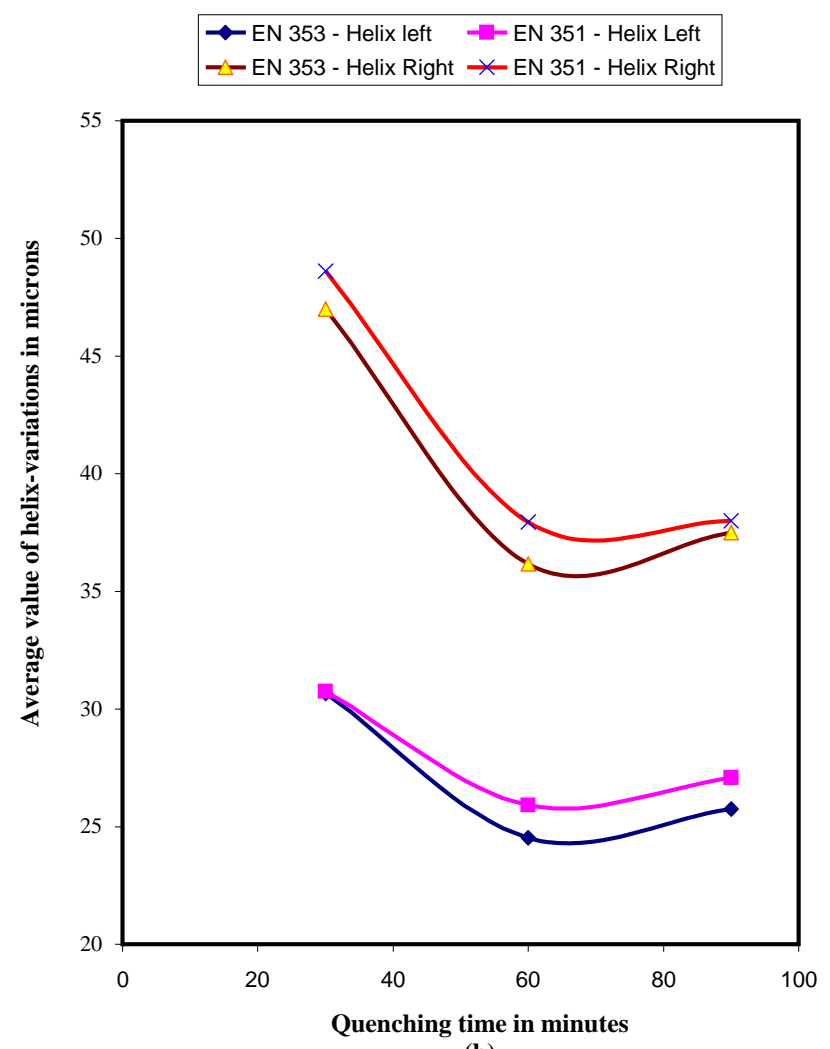

(b)

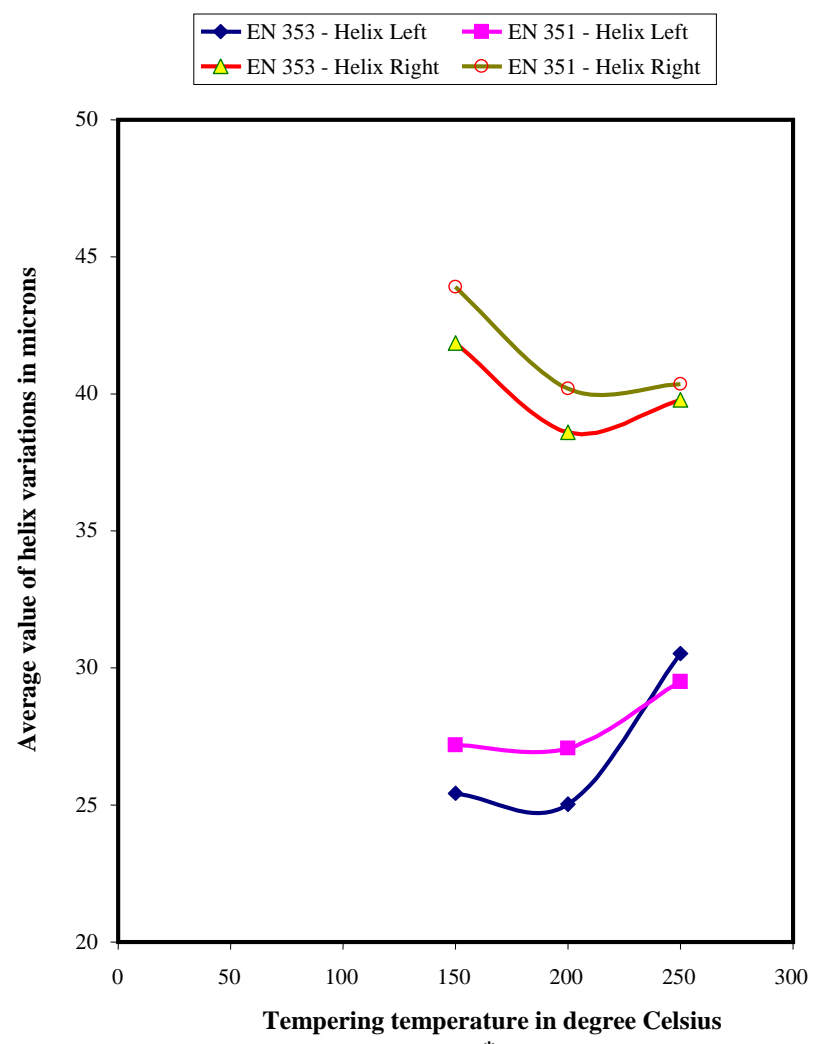

$\square$ F
(Fig. 2) contd....

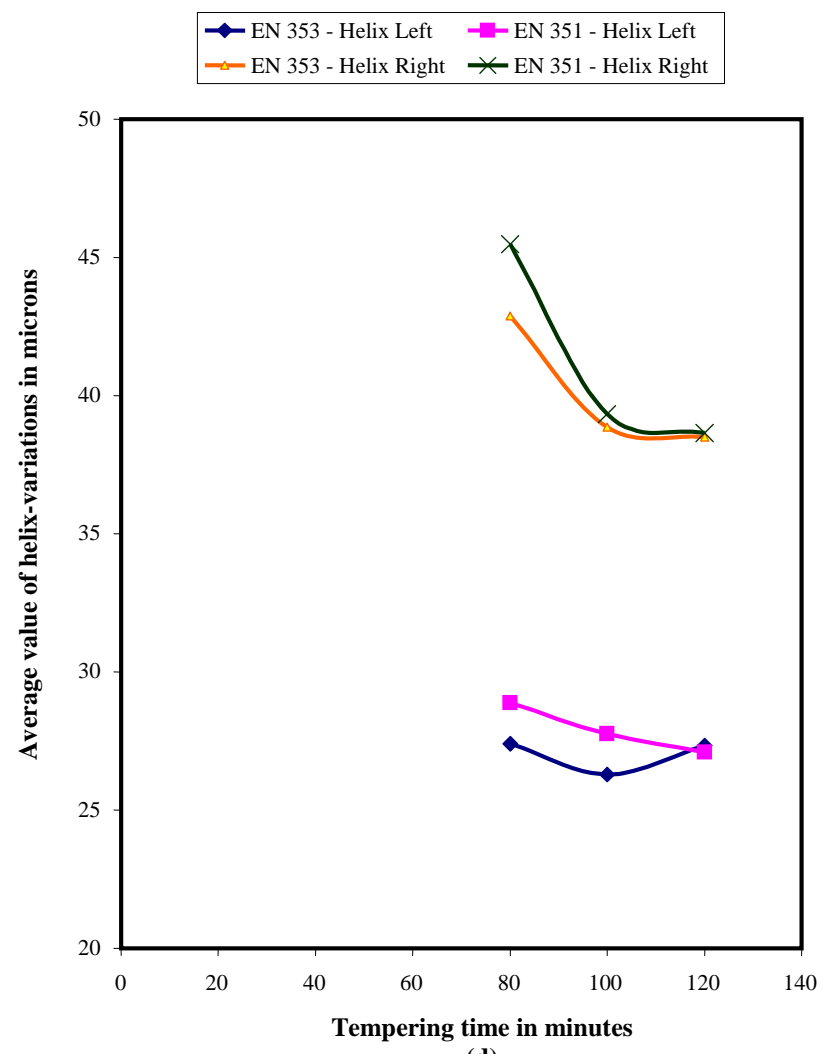

(d)

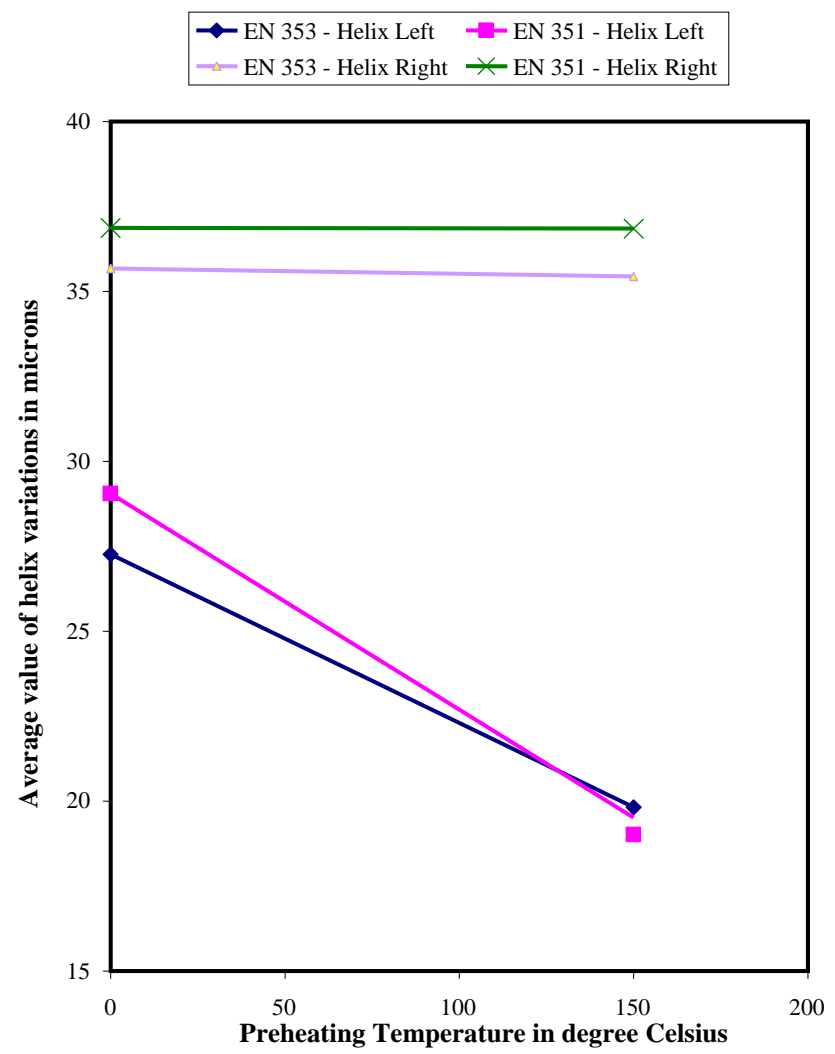

(e)

Fig. (2). (a-e) Process variables $v s$ Helix variations (Left and Right). 
Similarly, the percentage contributions of each variable on the helix variation- (Right) is calculated and given in the Table 11.

Table 11. Percentage Contribution of Each Variable on Helix Variations (Right)

\begin{tabular}{|l|c|c|}
\hline \multirow{2}{*}{\multicolumn{2}{|c|}{ Variables }} & \multicolumn{2}{c|}{$\begin{array}{c}\text { Helix Variation } \\
\text { (Right) }\end{array}$} \\
\cline { 2 - 3 } & EN 353 & EN 351 \\
\hline \hline Furnace temperature & $\mathbf{2 3 . 0 5 \%}$ & $\mathbf{2 4 . 0 4 \%}$ \\
\hline Quenching Time & $\mathbf{1 9 . 4 5 \%}$ & $\mathbf{2 1 . 0 2 \%}$ \\
\hline Tempering Temperature & $\mathbf{5 . 0 5 \%}$ & $\mathbf{3 . 8 4} \%$ \\
\hline Tempering Time & $\mathbf{7 . 1 2} \%$ & $\mathbf{8 . 9 2 \%}$ \\
\hline Preheating & $\mathbf{1 0 . 1 0 \%}$ & $\mathbf{7 . 8 3 \%}$ \\
\hline Furnace Temperature and Quenching time & $\mathbf{2 0 . 1 5 \%}$ & $\mathbf{1 9 . 6 2 \%}$ \\
\hline Furnace Temperature and Tempering Temperature & $\mathbf{6 . 5 2 \%}$ & $\mathbf{4 . 7 5 \%}$ \\
\hline Error & $\mathbf{8 . 5 6 \%}$ & $\mathbf{9 . 9 8 \%}$ \\
\hline
\end{tabular}

Optimum set of variables for helix variations (Right) are found by adopting the Lower is better strategy [8]. The results are given in Table 9. Predicted mean difference $\beta$ for helix variation (right) is calculated and given below.

EN 353 - 17.77 microns and EN 351 - 19.03 microns.

\section{Signal to Noise Ratio}

Formula to determine $\mathrm{S} / \mathrm{N}$ ratio for minimizing the response factor as the objective (Minimizing the run-out and helix variations) is, [9-10].

$\mathrm{S} / \mathrm{N}=-10 \log _{10}\left[\Sigma \mathrm{yi}^{2} / \mathrm{n}\right]$

where, yi - is the experimental response values for the trials, $\mathrm{n}$ - number of trials

$\mathrm{S} / \mathrm{N}$ ratio for run-out and helix variations (Left and Right) are calucated using the equation 3 . The model calculation is given below and the $\mathrm{S} / \mathrm{N}$ ratios for run-out, Helix variation (Left) and Helix variation (right) are listed in the Tables 2-4 respectively.

2.2.2.2. Model Calculation for the Material EN 353 - RunOut

$\mathrm{S} / \mathrm{N}$ ratio for minimizing the run-out $\left(12^{\text {th }}\right.$ Experiment run $)$

$$
\begin{gathered}
\mathrm{S} / \mathrm{N}=-10 \log _{10}\left[\left\{(0.03)^{2}+(0.06)^{2}\right\} / 2\right] \\
=26.478
\end{gathered}
$$
Left

Similarly for EN 351 steel material - Helix variation -

$\mathrm{S} / \mathrm{N}$ ratio for minimizing the variation in helix - left $\left(16^{\text {th }}\right.$ Experiment run)

$$
\begin{gathered}
\mathrm{S} / \mathrm{N}=-10 \log _{10}\left[\left\{(0.0423)^{2}+(0.0012)^{2}\right\} / 2\right] \\
=30.48
\end{gathered}
$$
Right

Similarly, for EN 353 steel material - Helix variation -

$\mathrm{S} / \mathrm{N}$ ratio for minimizing the variation in helix -left $\left(08^{\text {th }}\right.$ Experiment run)

$$
\begin{aligned}
\mathrm{S} / \mathrm{N} & =-10 \log _{10}\left[\left\{(0.0342)^{2}+(0.0252)^{2}\right\} / 2\right] \\
& =30.4463
\end{aligned}
$$

Optimum conditions for run-out and helix variations are found by adopting the higher the $\mathrm{S} / \mathrm{N}$ ratio is better as the strategy and results are given in the Table 9 for the materials EN 353 and EN 351. The optimum conditions result obtained in $\mathrm{S} / \mathrm{N}$ method matches with the optimum result obtained from the response graph analysis. It is significant to note that the optimum conditions for hardness, case depth, run out and helix variations are the same (Tables $\mathbf{7}$ and $\mathbf{9}$ in Paper 1).

\section{VOLUME AND DIMENSIONAL CHANGES IN INDUCTION HARDENING}

Induction hardening processes have been well developed and widely used in the various industrial applications especially in treating automobile transmission gears for several decades. However, due to the complex geometry of gears and the volume changes involved in the hardening process, it is very difficult to surface harden the gears with the required degree of consistency and quality. Minimization of changes in volume and accompanying dimensional changes arising from the high temperature heat treatment processes have been the critical issues.

The demerits involved in induction hardening are,

* Volume changes and dimensional changes which may require reworking

* Quench cracking

Excessive grain growth in the region just below the hardened surface in the Induction hardening process produces transformation stresses and thermal stresses. These stresses cause shape and size distortion in the components. The term 'distortion' usually describes the dimensional changes brought about by the relief of internal stresses, which occur in a component after heat treatment.

Several investigations have found it convenient to divide the total distortion into two classes of dimensional change. The first of these is usually called 'volume change' or 'inherent distortion' and is said to be the result of the dilations due to transformations. The second type of dimensional change is usually 'warpage' or 'change in shape' and is said to be associated with the thermal stresses produced by non-uniformity of heating or cooling. In this investigation, the term 'distortion' refers to the total dimensional change that has resulted from a particular heattreatment operation, namely Induction hardening [11].

The distortion has always presented difficulties to users of the many varieties of steels, which can be hardened by Induction hardening [12]. The dimensional change in Induction hardened components is troublesome to manufacturers. If the distortion is controlled within the tolerance limit, the post hardening processes can be eliminated by which cost and time can be saved [13]. With this aim, a study has been conducted in this present work to minimize the distortion level in the sample material (i.e. Rack made of AISI 4140 and AISI 9255).

The details of materials and operating conditions used in the experiments are shown in Table $\mathbf{1 2}$. 
Table 12. Materials and Operating Conditions

\begin{tabular}{|c|c|c|c|c|c|c|c|c|c|}
\hline \multirow{2}{*}{ S. No. } & \multirow{2}{*}{ Variables } & \multirow{2}{*}{ Unit } & \multirow{2}{*}{ Notation } & \multicolumn{3}{|c|}{ Levels Actual } & \multicolumn{3}{c|}{ Code } \\
\cline { 5 - 11 } & & & & Low & Medium & High & Low & Medium & High \\
\hline \hline 1 & Power potential & $\mathrm{kW} /$ inch $^{2}$ & $\mathrm{P}$ & 5.5 & 7.05 & 8.5 & $\mathrm{~L} 1$ & $\mathrm{~L} 2$ & $\mathrm{~L} 3$ \\
\hline 2 & Scan speed & $\mathrm{m} / \mathrm{min}$ & $\mathrm{S}$ & 1.34 & 1.72 & 2.14 & $\mathrm{~L} 1$ & $\mathrm{~L} 2$ & $\mathrm{~L} 3$ \\
\hline 3 & Quench flow rate & Litres/min & $\mathrm{Q}$ & 15 & 17.5 & 20 & $\mathrm{~L} 1$ & $\mathrm{~L} 2$ & $\mathrm{~L} 3$ \\
\hline
\end{tabular}

Table 13 shows the experimental results in the $3^{3}$ Design Matrix for the materials AISI 4140 and AISI 9255 respectively.

Tables 14 and 15 show the ANOVA with F-Test for the materials AISI 4140 and AISI 9255 respectively.

The experiments have been conducted based on $3^{3}$ full factorial DOE.

Table 13. $3^{3}$ Design Matrix for Induction Hardening with Test Results

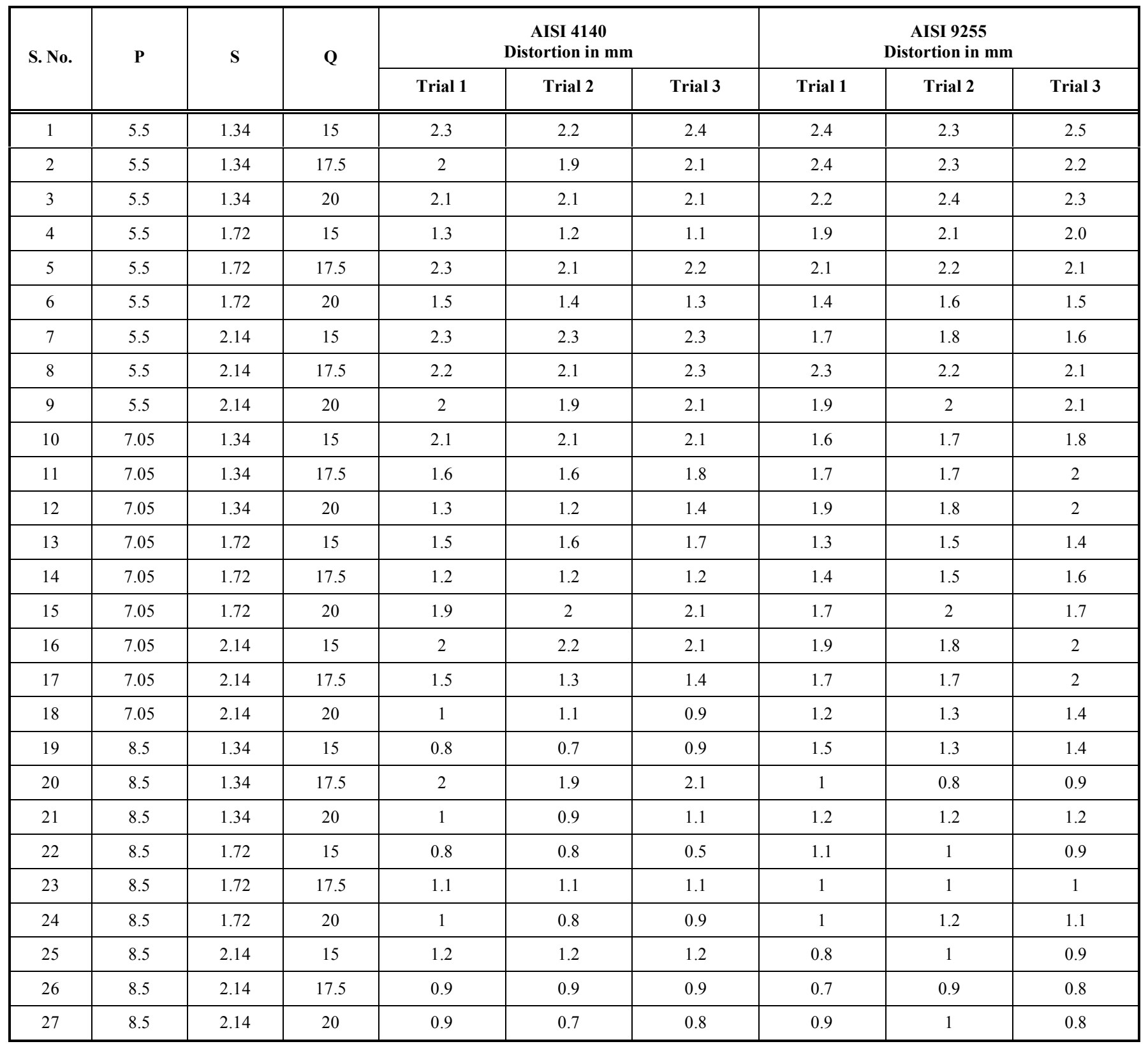

3.1. Influence of Main Variables on Distortion of Rack Material

\subsubsection{Model Calculation}

Total sum of the run

$$
=(2.4+2.3+2.5+\ldots \ldots \ldots .0 .9+1.0+0.8)=128.4
$$


Number of Treatments $=3$ (3 Factors)

Number of Levels $=3$

Number of replicates (r) $=3$

Total of the observations under all factor levels, $=\mathrm{N}=\mathrm{abcr}=3 \times 3 \times 3 \times 3=81$

Correction factor, $(\mathrm{C})$ $=(128.4)^{2} / 81 \quad=203.5$

Sum of Squares of Treatment, (SST) $=\left(2.4^{2}+2.3^{2}+2.5^{2}+\ldots 0.9^{2}+1^{2}+0.8^{2}\right)$

$=223.04-\mathrm{C}=19.54$

Sum of Squares of Treatment with replicates, $\left(\mathrm{SST}_{\mathrm{r}}\right)$ $=1 / 3\left(7.2^{2}+6.9^{2}+\ldots .2 .7^{2}\right)$

$=1 / 3(667.3)-\mathrm{C}=18.93$

Sum of Squares of Replicate, $(\mathrm{SSR})=$

$1 / 27\left(41.8^{2}+43.3^{2}+43.3^{2}\right)-\mathrm{C}$ $=0.093$

Sum of Squares of Error, (SSE) $=\mathrm{SST}_{-\mathrm{SST}_{\mathrm{r}}}-\mathrm{SSR}=19.54-18.93-0.093=0.517$

\begin{tabular}{|c|c|c|c|c|c|c|c|c|c|c|c|}
\hline & \multicolumn{3}{|c|}{$\mathbf{S}$} & & \multicolumn{3}{|c|}{$\mathbf{Q}$} & & \multicolumn{3}{|c|}{$\mathbf{Q}$} \\
\hline 55.5 & 21 & 16.8 & 17.7 & \multirow{3}{*}{$\mathrm{P}$} & & & & 47.7 & 16.5 & 15 & 16.2 \\
\hline 45.3 & 16.2 & 14.1 & 15 & & & & & 40.2 & 13.5 & 13.5 & 13.2 \\
\hline 27.6 & 10.5 & 9.3 & 7.8 & & & & & 40.5 & 13.5 & 14.4 & 12.6 \\
\hline 128.4 & 47.7 & 40.2 & 40.5 & 55.5 & 18.6 & 19.5 & 17.4 & 128.4 & 43.5 & 42.9 & 42 \\
\hline \multirow{3}{*}{$\mathrm{P}$} & & & & 45.3 & 15 & 15.3 & 15 & \multirow{3}{*}{$\mathrm{S}$} & & & \\
\hline & & & & 27.6 & 9.9 & 8.1 & 9.6 & & & & \\
\hline & & & & 128.4 & 43.5 & 42.9 & 42 & & & & \\
\hline
\end{tabular}

\subsubsection{Sum of Squares of Main Effect (P, S and $Q)$}

Sum of Square of Power Potential,

$\mathrm{SSP}=\left[1 / 27\left(55.5^{2}+45.3^{2}+27.6^{2}\right)\right]-\mathrm{C} \quad=14.8$

Sum of Square of Scan Speed,

$\mathrm{SSS}=\left[1 / 27\left(47.7^{2}+40.2^{2}+40.5^{2}\right)\right]-\mathrm{C} \quad=1.373$

Sum of Square of Quench flow rate, SSQ

$$
\begin{gathered}
=\left[1 / 27\left(43.5^{2}+42.9^{2}+42^{2}\right)\right]-\mathrm{C} \\
=0.08
\end{gathered}
$$

3.1.3. Two Way Interactions of Sum of Squares (PS, $S Q$ and $P Q$ )

Sum of Square of Power Potential and Scan Speed

$$
=\left[1 / 9\left(21^{2}+\ldots 7.8^{2}\right)\right]-\mathrm{C}=0.367
$$

Sum of Square of Scan Speed and Quench flow rate

$$
=\left[1 / 9\left(16.5^{2}+\ldots .12 .6^{2}\right)\right]-\mathrm{C}=0.247
$$

Sum of Square of Power Potential and Quench flow rate

$$
=\left[1 / 9\left(18.6^{2}+\ldots 9.6^{2}\right)\right]-\mathrm{C}=0.380
$$

\subsubsection{Three Way Interactions of Sum of Square (PSQ)}

Sum of Square of Power Potential, Scan speed and Quench flow rate

$$
\begin{aligned}
& =\mathrm{SST}_{\mathrm{r}}-\{\text { SSP-SSS-SSQ-SSPS- SSSQ-SSPQ }\} \\
& =18.93-14.8-1.373-0.08-0.367-0.247-0.38=1.683
\end{aligned}
$$

Regression analysis has been done using MATLAB and the Regression equations (Equation to predict the distortion of the material AISI 4140) have been arrived at. The results are given below.

AISI 4140

Coeff $=$

\begin{tabular}{|c|c|c|c|c|c|}
\hline Variable & Sum of Squares & Degrees of Freedom & Mean Square & $\mathbf{F}$ & Significant Ranking \\
\hline Replicates & 0.0574 & 2 & 0.0287 & 3.776 & - \\
\hline $\mathrm{P}$ & 5.549 & 2 & 2.7745 & 365.065 & 1 \\
\hline $\mathrm{S}$ & 5.1935 & 2 & 2.5965 & 341.644 & 2 \\
\hline Q & 1.00976 & 2 & 0.50488 & 66.431 & 6 \\
\hline PS & 4.678 & 4 & 1.1695 & 153.881 & 3 \\
\hline SQ & 3.82124 & 4 & 0.95531 & 125.698 & 4 \\
\hline PQ & 2.07124 & 4 & 0.51781 & 68.132 & 5 \\
\hline PSQ & 0.69446 & 8 & 0.0868 & 11.421 & 7 \\
\hline ERROR & 0.3959 & 52 & 0.0076 & - & \\
\hline TOTAL & - & 80 & & & \\
\hline
\end{tabular}

$1.00005 .50001 .340015 .0000 \quad 2.3$

$1.00005 .50001 .340017 .5000 \quad 2.0$

$1.00005 .50001 .340020 .0000 \quad 2.1$

$1.00005 .50001 .720015 .0000 \quad 1.2$

$1.00005 .50001 .720017 .5000 \quad 2.3$

Table 14. ANOVA with F-Test - Material: AISI 4140 
Table 15. ANOVA with F-Test - Material: AISI 9255

\begin{tabular}{|c|c|c|c|c|c|}
\hline Variable & Sum of Squares & Degrees of Freedom & Mean Square & $\mathbf{F}$ & Significant Ranking \\
\hline Replicates & 0.093 & 2 & 0.0465 & 4.696 & - \\
\hline $\mathrm{P}$ & 14.8 & 2 & 7.4 & 747.474 & 1 \\
\hline S & 1.373 & 2 & 0.6865 & 69.343 & 2 \\
\hline Q & 0.08 & 2 & 0.04 & 4.040 & 7 \\
\hline PS & 0.367 & 4 & 0.09175 & 9.267 & 5 \\
\hline SQ & 0.247 & 4 & 0.06175 & 6.237 & 6 \\
\hline PQ & 0.380 & 4 & 0.095 & 9.595 & 4 \\
\hline PSQ & 1.683 & 8 & 0.210 & 21.212 & 3 \\
\hline ERROR & 0.517 & 52 & 0.0099 & - & \\
\hline TOTAL & - & 80 & & & \\
\hline
\end{tabular}

1.00005 .50001 .720020 .0000

1.4

1.00005 .50002 .140015 .0000

2.3

1.00005 .50002 .140017 .5000

2.2

1.00005 .50002 .140020 .0000

2.0

1.00007 .05001 .340015 .0000

2.1

1.00007 .05001 .340017 .5000

1.6

1.00007 .05001 .340020 .0000

1.3

1.00007 .05001 .720015 .0000

1.6

1.00007 .05001 .720017 .5000

1.3

1.00007 .05001 .720020 .0000

2.0

1.00007 .05002 .140015 .0000

2.1

1.00007 .05002 .140017 .5000

1.4

1.00007 .05002 .140020 .0000

1.0

1.00008 .50001 .340015 .0000

0.8

1.00008 .50001 .340017 .5000

2.0

1.00008 .50001 .340020 .0000

1.0

1.00008 .50001 .720015 .0000

0.7

1.00008 .50001 .720017 .5000

1.1

1.00008 .50001 .720020 .0000

1.0

1.00008 .50002 .140015 .0000

1.3

1.00008 .50002 .140017 .5000

0.9

1.00008 .50002 .140020 .0000

0.8 are,

The coefficients for the formation of distortion equation

\subsection{0 \\ $-0.1993$ \\ $-0.3480$ \\ $-0.0711$} 4140 ,
$Y_{D}=4.7850-0.1993 P-0.3480 S-0.0711 Q$

Similarly for the material AISI 9255,

$Y_{D}=4.6698-0.3415 P-0.3195 S-0.0078 Q$

\section{RESULTS AND DISCUSSION}

\subsection{Surface Hardening- Gas Carburizing}

The pinion material surface is case hardened by Gas carburizing heat treatment process. For the desired application, the case depth required is between $0.8-1.00 \mathrm{~mm}$ and the hardness between 79-82 HRA.

Distortion, is the major defect faced in gas carburizing process. Distortion here refers to Run-out and unwinding of helix angle in pinion [14]. To minimize the distortion level in pinion and to analyze the experimental data by Response graph method and Signal to Noise method the values of Runout and helix variations (Left and Right) are checked for the materials EN353 and EN351.

Average effect of the main variables on Run-out, Left and Right helix variations for the materials EN353 and EN351 are shown in the Tables 5-7. Corresponding Response graphs, Figs. (1a-e, 2a-e) are drawn.

Even though, EN 351 and EN 353 are having same carbon percentage, EN 353 gives minimal dimensional and volume changes because of the presence of three alloying elements namely Cobalt, Molybdenum and Nickel. These steels have properties which are superior to corresponding double alloy steels ie. (Nickel and Chromium) alloy steels. Under optimum conditions, the distortions for the above said materials are given in the Table $\mathbf{1 6}$ below (taken from Tables 2-4) and it validates the above said statement.

Table 16. Distortion Level Under Optimal Conditions Materials: EN 351 and EN 353

\begin{tabular}{|c|c|c|c|c|}
\hline \multirow{2}{*}{ S. No. } & \multirow{2}{*}{ Materials } & \multirow{2}{*}{$\begin{array}{c}\text { Run-Out } \\
\text { in Microns }\end{array}$} & \multicolumn{2}{|c|}{ Helix Variations in Microns } \\
\cline { 4 - 5 } & & & Left & Right \\
\hline \hline 01 & EN 351 & 36 & 4.5 & 20.4 \\
\hline 02 & EN 353 & 21 & 0.7 & 20.4 \\
\hline
\end{tabular}


(a)

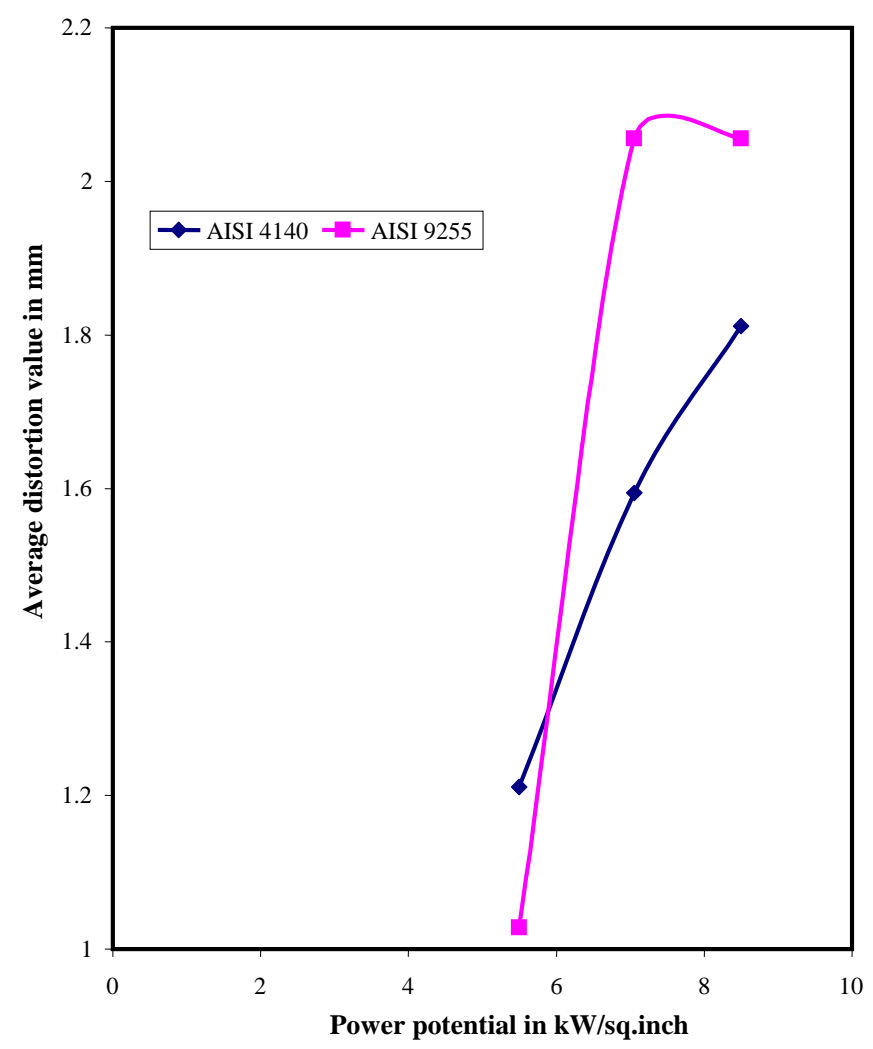

(b)

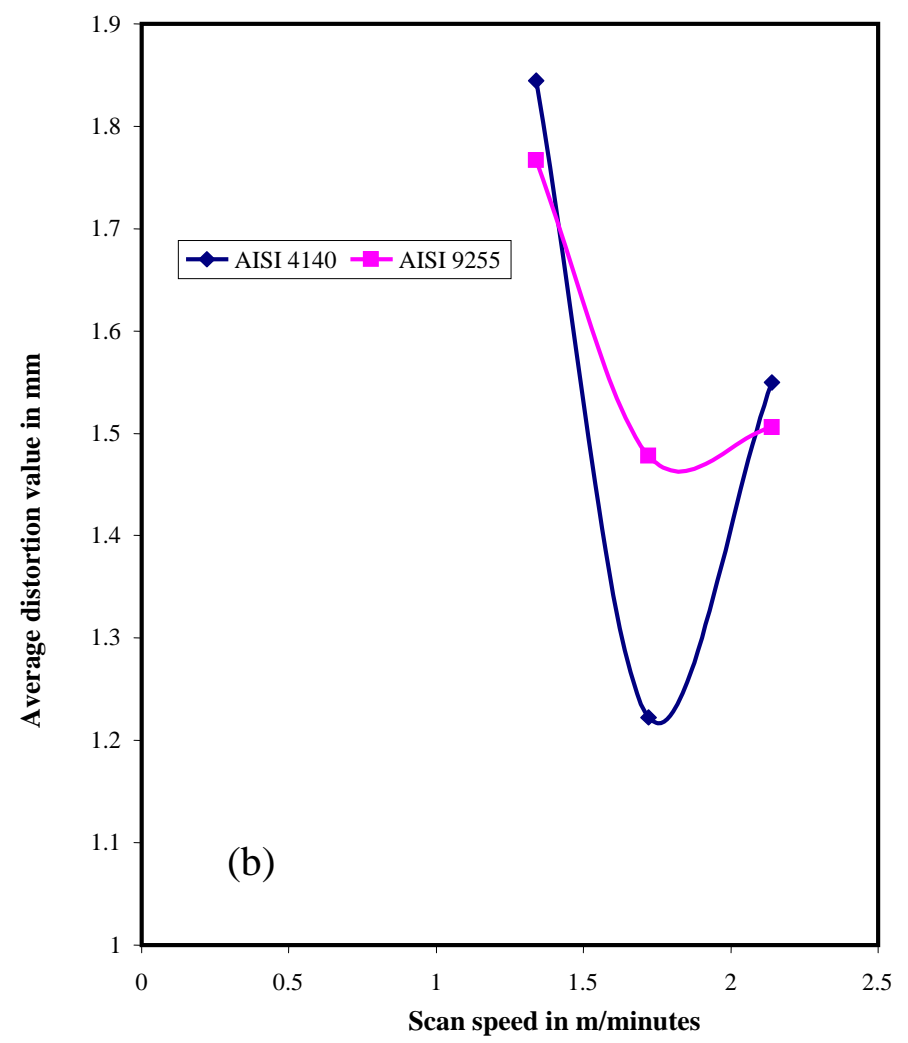

(c)

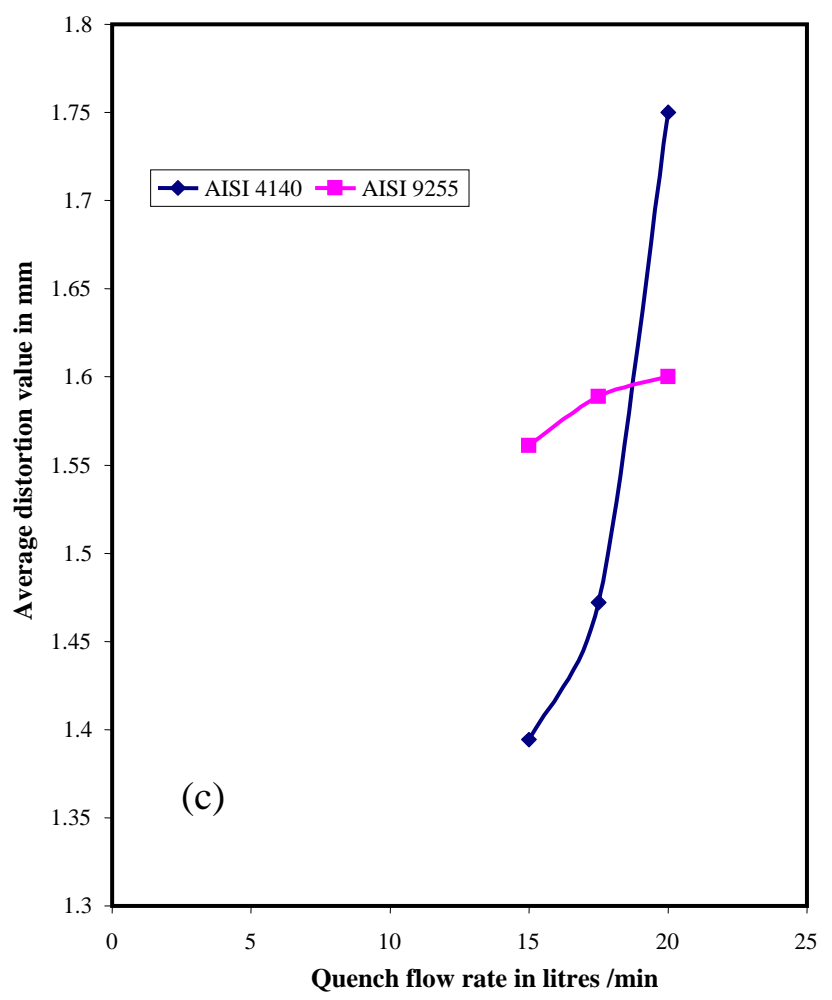

Fig. (3). (a-c) Process variables vs Distortion.

Analysis of variance is done for EN 353 and EN 351. The ANOVA results (Tables 8, 10 and 12) and optimum conditions (Tables 9, 11 and 13) indicate that the interaction between Furnace temperature and quenching time is having more influence on the distortion. Confirmation trail for optimum condition is carried out and results are tabulated in Table $\mathbf{1 7}$ and it shows that a good agreement between the experimental results and predicted optimum results. The percentage deviation between the experimental and predicted results for the runout and helix variations is in the range of 7 to $10 \%$.

Similarly, Signal to noise ratio method has also given the same optimal variable levels/best treatment combination levels for the materials EN353 and EN 351 (Table 4).

At present, straightening operation is required to remove the bend in a 5 tons Hydraulic press as it occurs during the heat treatment process. Straightening operation incurs additional manpower and cost of manufacturing. This may be clear from the following cost analysis.
Pinion manufacturing cost
: Rs. 80/-
Re-working cost
: Rs. 8/-

Average number of pinion produced per annum : 75,000 nos. Average percentage of rejection of pinion : $10 \%$ (7,500 nos.) 


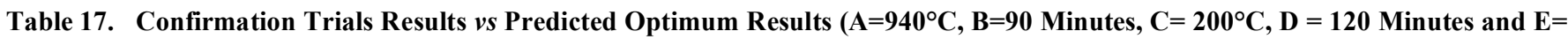
$\left.150^{\circ} \mathrm{C}\right)$

\begin{tabular}{|c|c|c|c|c|c|c|c|c|}
\hline \multirow{3}{*}{ Trials } & \multicolumn{4}{|c|}{ Experimental Results } & \multirow{2}{*}{\multicolumn{4}{|c|}{ Predicted Optimum Results for Run-Out and Helix-Variations }} \\
\hline & \multicolumn{2}{|c|}{ Run-Out in Microns } & \multicolumn{2}{|c|}{ Helix-Variation (Left and Right) } & & & & \\
\hline & EN 353 & EN 351 & EN 353 & EN 351 & EN353 & EN351 & EN353 & EN351 \\
\hline 1 & 30 & 27 & 10.6 & 11.05 & \multirow{5}{*}{33.998} & \multirow{5}{*}{34.224} & \multirow{5}{*}{18.684} & \multirow{5}{*}{16.410} \\
\hline 2 & 32 & 34 & 20.11 & 15.10 & & & & \\
\hline 3 & 28 & 30 & 18.46 & 17.85 & & & & \\
\hline 4 & 30 & 32 & 21.22 & 18.15 & & & & \\
\hline 5 & 34 & 31 & 15.0 & 13.12 & & & & \\
\hline
\end{tabular}

Cost of rejection per annum : $7500 * 88 * 12$

$$
\begin{aligned}
& \text { : Rs.7.2 lakhs (approx.) } \\
& \text { : \$US 15,000/- (approx.) }
\end{aligned}
$$

Hence, introduction of optimum conditions gives great economical benefits and increases the rate of production [15].

In Gas carburization, by eliminating the final straightening operation cost saved per year is Rs.7.0 Lacs. (US\$ 15,000) and the time saved per loading is 6 hours.
The present study shows that under optimum conditions the pinion product obtained do not require any re-working process. This is due to the fact that under optimum treatment combination, the Run-out in pinion is within 30 microns and unwind of helix angle is within 40 microns, which are well within the maximum permissible limits [16].

To study the metallurgy of Gas carburized components microstructures (Case-core portion) are taken and given in Figs. (4-6).

A carburized case is usually a mixture of tempered marteniste and retained austenite (Fig. 4). Other micro

Mixture of tempered martensite

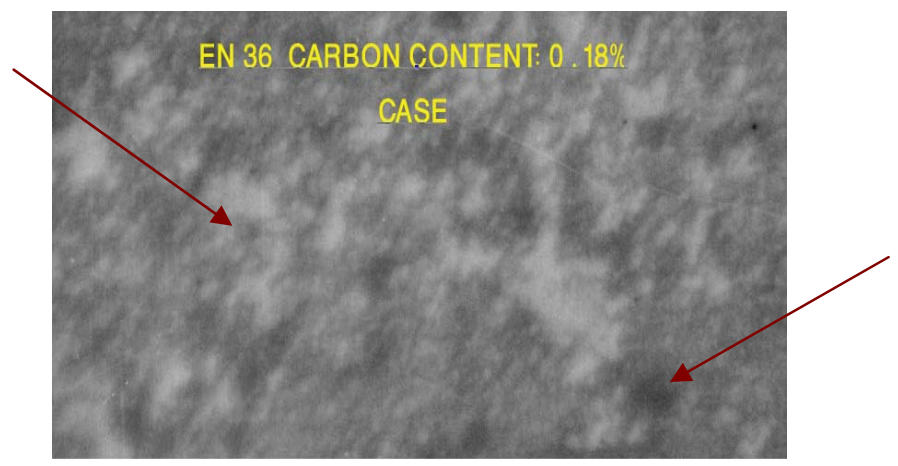

Fig. (4). Mixture of tempered martensite and retained austenite of the Case (EN 36).

\section{Case to Core Transition zone}

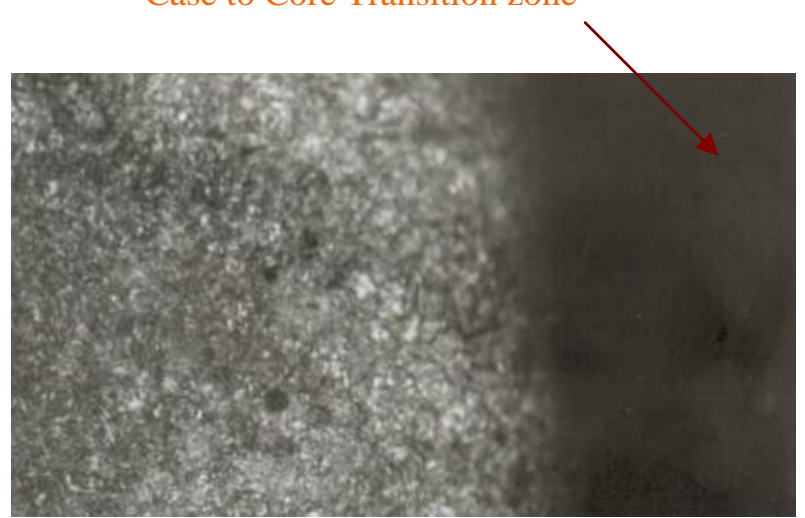

CASE

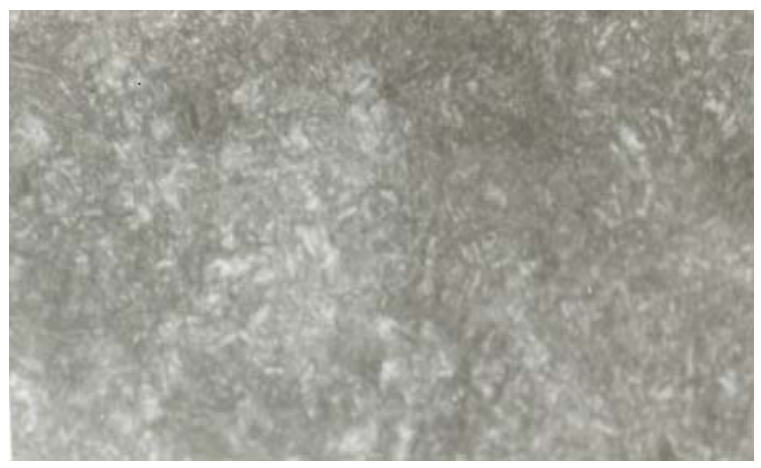

CORE

Fig. (5). Microstructure of Case and Core portion of EN 353 pinion material. 


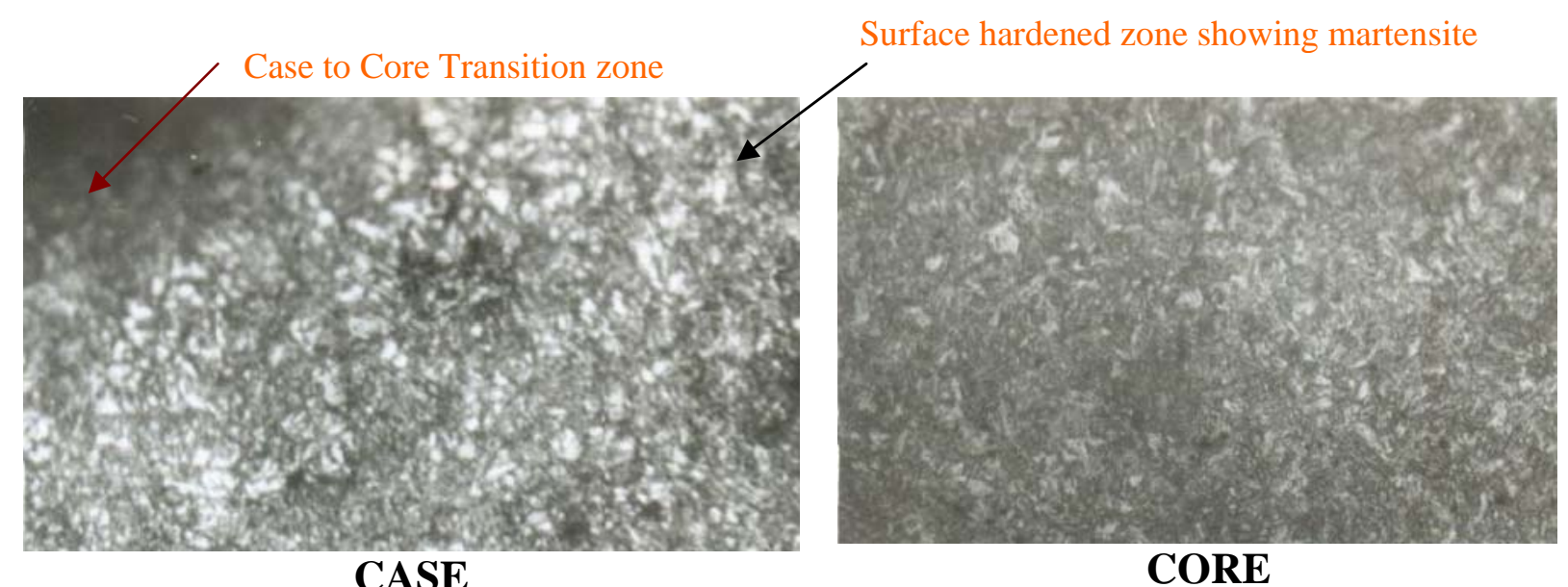

Fig. (6). Microstructure of Case and Core portion of EN 351 pinion material.

constituents, such as primary carbides, bainite, and pearlite are generally avoided [17]. For a particular alloy, the amount of retained austenite in the case increases as the case carbon content increases [18]. An appreciable decrease in case hardness is usually found when the amount of retained austenite exceeds about $15 \%$, but for applications involving contact loading, such as rolling element bearings, best service life is found when the retained austenite content is quite high, for example, 30 to $40 \%$ [19-20] In other applications, especially when dimensional stability is critical, the retained austenite content should be low.

The microstructures (Figs. 5, 6) reveal that there is a martensitic formation in the case hardened portion and there is no abnormal microstructural change in the core portion.

\subsection{Surface Hardening - Induction Hardening}

The rack material surface is hardened by Induction hardening process. The case depth below the teeth is $1.5-2$ $\mathrm{mm}$ and back of the bar is $3.5-4 \mathrm{~mm}$. The hardness between 79-82HRA.

Transformation and Thermal stresses cause shape and size distortion in the induction hardened components [21]. To minimize the distortion level in Rack and to analyze the experimental data by F-Test the values of distortion are checked for the materials AISI 4140 and AISI 9255. Table 13 shows the distortion of the Rack materials obtained as per the $3{ }^{3}$ Factorial Design matrix [22].

Analysis of variance is done for AISI 4140, and AISI 9255. The ANOVA results and F-Test results (Tables 14 and 15) show that Power potential has more influence on case hardness and case depth of the Induction hardened components. In order to obtain the significance and effect of each factor and their interaction, the sum of the squares, Degrees of freedom, Mean square and $\mathrm{F}$ are calculated first. Based on these calculations the Ranking and significance of each variable have been found out. It is observed that Power potential, and Scan speed occupies the number one and number two ranking.

Influence of Scan speed (heating time) - Only the outer region of samples are affected by the Induction hardening process. Consequently, the temperatures decrease with increase in distance from the surface. The core of the Rack remains completely cold. If the scan speed is too high, say $2.14 \mathrm{~m} /$ minutes, the induction heating effect is very less. On the other hand, with less scan speed, say $1.34 \mathrm{~m} /$ minutes, heating effect is more and the material becomes too hard (Pantleon, K., et al., 1999) [23].

The medium scan speed of $1.72 \mathrm{~m} /$ minutes gives a better result in which the temperature rises uniformly and the temperature distribution becomes uniform over the surface of the material. During the Induction hardening process the surface region of the samples are heated up for several seconds to about $800-850^{\circ} \mathrm{C}$ [24]. Temperature gradient finally results in microstructure gradients.

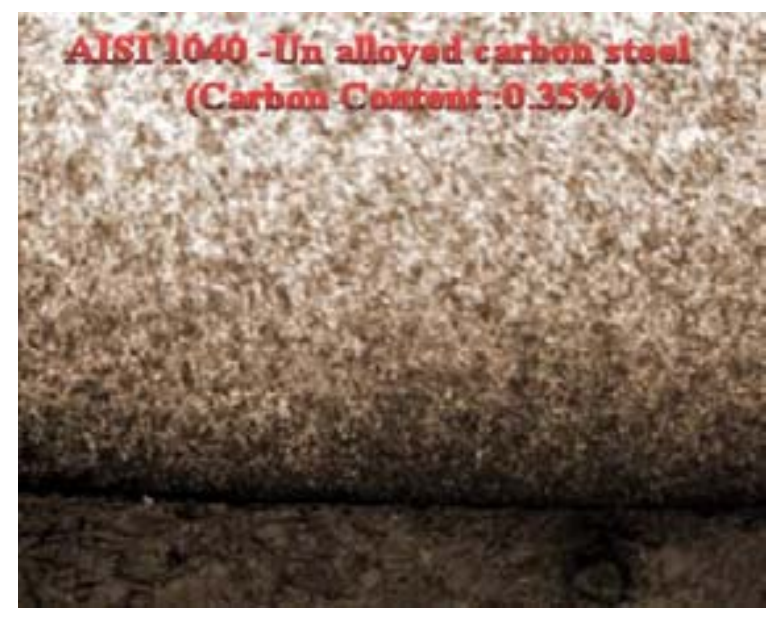

Fig. (7). Case - core interface showing martensite in the case and ferrite/pearlite in the core region.

Near the interface (Fig. 7), the microstructure consists of martensite. But the core of the component still shows a ferritic pearlitic microstructure with no differences to the samples as deposited [25-26]. From the, etching of cut section as shown in Fig. (8) it can be concluded that the depth of the hardened zone is uniform over most of the samples. 


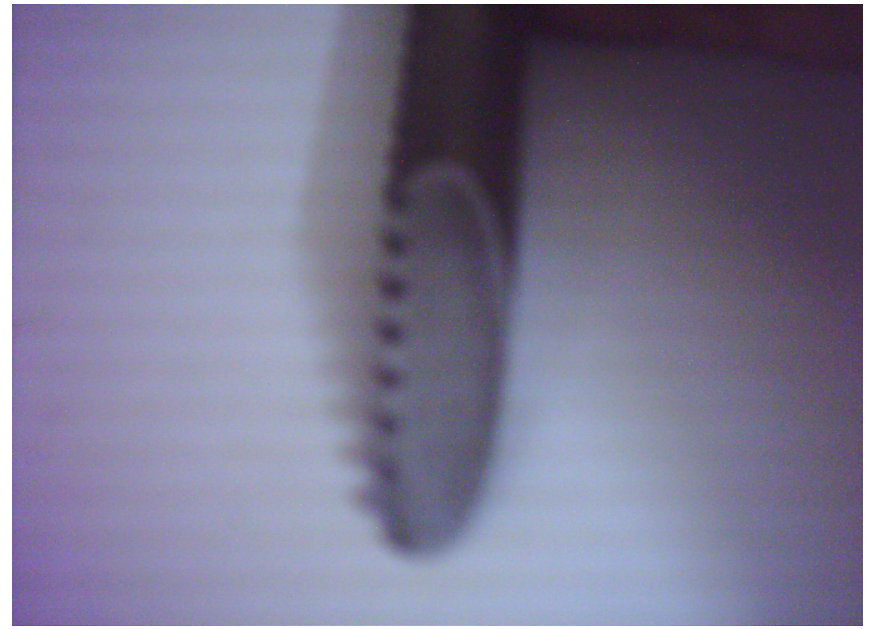

Fig. (8). Cut- section of a Rack showing the uniform case-depth.

Fig. (3a-e) shows that under optimal conditions (Power potential $5.5 \mathrm{~kW} / \mathrm{inch}^{2}$, Scan speed $1.72 \mathrm{~m} /$ minutes and Quench flow rate (15 litres $/ \mathrm{min})$ the distortion is very low for both AISI 4140 and AISI 9255 with required hardness and case depth.

In the investigations, it has been found that the maximum of hardness 83HRA with low distortion of $1.5 \mathrm{~mm}$ (Under non-optimal condition the distortion was $3.5 \mathrm{~mm}$ ) for the distortion Induction hardened specimen at the optimal condition. Regression analysis is done, controlling equation to predict the distortion of Induction hardened components at any parametric conditions has been developed, and the same are given below.

$Y_{D}=4.7850-0.1993 P-0.3480 S-0.0711 Q$ (AISI 4140)

$Y_{D}=4.6698-0.3415 P-0.3195 S-0.0078 Q$ (AISI 9255)

\subsection{SEM and Crack Detection Analysis}

Under abnormal heat treatment conditions thermal damages occur [27]. However, under optimal conditions the surface hardened components (both Gas carburizing and Induction hardening) show that there is a significant improvement in the hardness and case depth [28-29] Scanning electron microscope analysis is done for few samples and the structures are given in Figs. $(\mathbf{9}, \mathbf{1 0})$. It shows that there is a moderate conversion of austenite to martensite in the case hardened region.

The microstructure of soft material (EN 34) before gas carburizing is shown in Fig. (11). It shows that the presence of Ferrite/pearlite in the complete volume of the material. This ferrite /pearlite transformed into austenite on heating and converted into martensite while cooling [30].

A liquid solution containing very tiny magnetic particles is sprayed on the surface being checked and the sample is then subjected to a strong magnetic field. Discontinuity at or near the surface of the metal creates free poles. When magnetized, the metal attracts the magnetic particles in the solution used. When the magnetic field is removed, magnetic particles are left behind and get concentrated at those sites, thereby revealing the defects. The magnetic field is set up in the samples by using a power electromagnet.

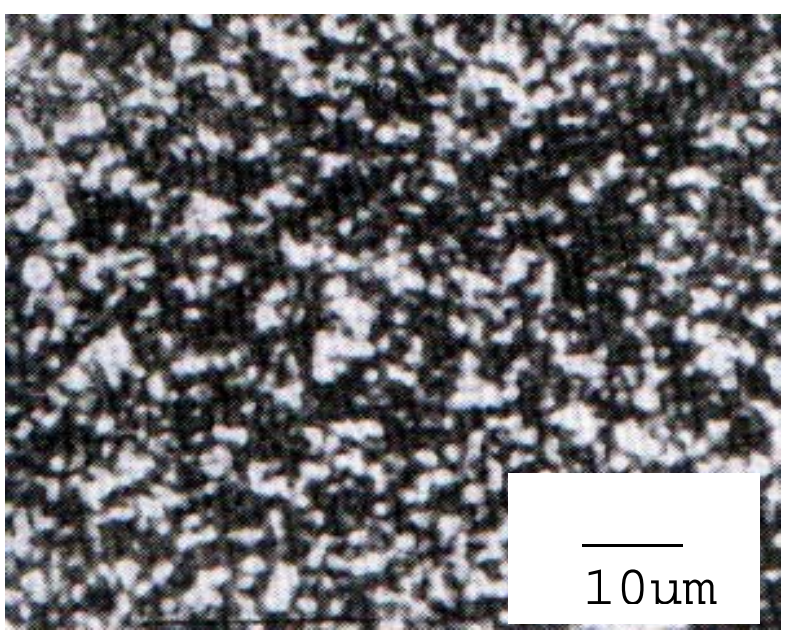

Fig. (9). Micrograph for gas carburized specimen (EN 34).

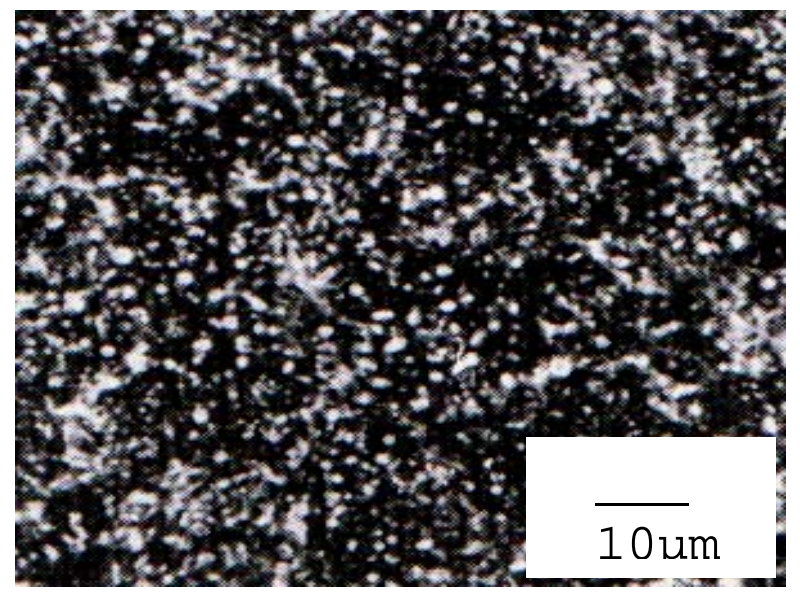

Fig. (10). Micrograph for induction hardened specimen (AISI 6150).

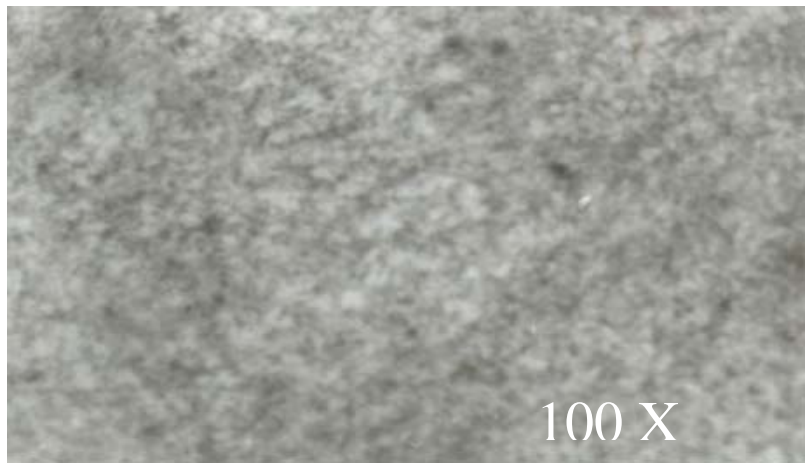

Fig. (11). Microstructure of EN 34 before gas carburizing showing the presence of ferrite/pearlite.

Crack detection analysis shows that, there are no micro and macro cracks in the surface hardened components which are heat treated by Gas carburizing and Induction hardening process. 


\section{CONCLUDING REMARKS}

- Under optimum treatment combination, it is observed that the Run-out in pinion is within 30 microns and unwind of helix angle is within 40 microns which are well within the designed values.

- Under optimal conditions, the products obtained do not require any reworking process (Straightening operation).

- Introduction of optimum conditions gives great economical benefits and increases the rate of production.

In Gas carburization, by eliminating the final straightening operation cost saved per year is Rs.7.0 Lacs. (US\$ 15,000) and the time saved per loading is 6 hours.

- In the investigations, it has been found that the maximum of hardness 83HRA with low distortion of $1.5 \mathrm{~mm}$ for the distortion Induction hardened specimen at the optimal condition.

- Crack detection test shows that under optimal conditions case hardened components are free from surface/sub-surface discontinuities.

\section{ACKNOWLEDGEMENTS}

The authors are thankful to Rane (Madras) Pvt. Ltd., Thirubhuvanai, Pondicherry and IGCAR Kalpakkam for providing the experimental, testing and measurement facilities.

\section{REFERENCES}

[1] Bullens DK. Steel and its heat treatment. New York: John Wiley \& Sons, Inc. 1949; Vols. (1-3).

[2] Burnett JA. Prediction of stress history in carburized and quenched steel cylinders. Mater Sci Technol 1985; 1: 863-71.

[3] Butler DW. A stereo electron microscope technique for micro topographic measurements. Micron 1973; 4: 410-24.

[4] Jang JW, Park IW, Kim KH, Kang SS. FE program development of predicting thermal deformation in heat treatment. Int $\mathrm{J}$ Mater Process Technol 2002; 130-131: 546-50.

[5] Taguchi G. System of experimental design. New York: Unipub, karus International Publications 1987.

[6] Totten GE. Heat treating in 2020: what are the most critical issues and what will the future look like? Heat Treat Metal 2004; 31(1): 13 .

[7] Robinson GH. The effect of surface condition on the fatigue resistance of hardened steel, fatigue durability of carburized steel. American Society for Metals. Ohio: Cleveland 1957; pp. 11-46.
[8] Komanduri R, Hou ZB. Thermal analysis of laser surface transformation hardening - optimization of process parameters. Int J Mach Tools Manuf 2004; 44: 991-1008.

[9] Philip RJ. Taguchi techniques for quality engineering. Singapore: Mc Graw Hill 1989.

[10] Rout BK. Design of experiments and taguchis' quality engineering, ugc refresher course on world class manufacturing, December $8^{\text {th }}$ to $28^{\text {th }}$, BITS Pilani 2003; pp. 50-68.

[11] Osborn HB. Surface hardening by induction heat. Metal Prog 1955; 105-9.

[12] Cajner F, Smoljan B, Landek D. Computer simulation of induction hardening, Int J Mater Process Technol 2004; 157-158: 55-60.

[13] Juran, Joseph M. Quality Control Handbook, $4^{\text {th }}$ Ed. New York: McGraw-Hill Book Company 1980.

[14] Malhotra CP, Sahay SS. Model - based control of heat treatment operations, conference proceeding of ASM heat treat show. Mumbai 2002.

[15] Deshpande AM, Pandey C, Pant A, Sahay SS. Optimization of carburization profile for minimizing the process cost. Proceedings of International Conference on Advances in Surface Treatment: Research \& Applications. Hyderabad, India 2003; pp. 1-7.

[16] Sahay SS, Malhotra CP. Model based optimization of heat treatment operations. Proceedings of ASM Heat Treat Show. Mumbai 2002.

[17] Chen JR, Tao YQ, Wang HG. A study on heat conduction with variable phase transformation composition during quench hardening. Int J Mater Process Technol 1997; 63: 554-8.

[18] Dieter GE. Mechanical metallurgy. New York: McGraw-Hill 1981.

[19] Goodhew PJ. Electron microscopy and analysis. London: Wykeham 1975; pp. 9-13.

[20] Grosch LD, Kallhardt K, Tacke D, Hoffmann R, Luiten CH, Eysell FW. Gas carburizing at temperatures above $950^{\circ} \mathrm{C}$ in conventional furnaces and in cacuum furnaces. Hårterei-Technische Mitteilungen 1981; 36: 262-9.

[21] Child HC. Surface hardening of steels. London: Oxford University Press 1980.

[22] Dietmar H. A mathematical model for induction hardening including mechanical effects. Int J Nonlinear Anal 2004; 5: 55-90.

[23] Pantleon K, Kessler O, Hoffann F, Mayr P. Induction surface hardening of hard coated steels. Int J Surf Coat Technol 1999: 120121: 495-501.

[24] Payson. The annealing of steel. Iron Age 1943: 15 and 22.

[25] Siedel W, Netz W. Predicting by calculations, the results of induction heating. Hardening Technol 1982; 5: 211-9.

[26] Sphepeyakovskii K. Technology of heat treatment using induction heating, Mettalavendenie I. Termicheskaya Obrabotka Metallov Say 1987; 8: s.2-s.10.

[27] Kawase Y. Thermal analysis of steel blade quenching byinduction heating. IEEE Trans Magnet 2000; 36(4): 1788- 91.

[28] Crawford CK. Charge neutralization using very low energy electrons. Scann Electron Microsc 1979; 2(31): 31-46.

[29] Davies DE. Practical experimental metallurgy. New York: Elsevier 1966.

[30] Holburn DM, Smith KCA. On-line topographic analysis in the SEM. Scann Electron Microsc 1979; 12 (31): 47. 